\title{
The West Virginia Uncovered eTrainer; creating an online multimedia training guide
}

\author{
Jessica M. Rhodes \\ West Virginia University
}

Follow this and additional works at: https://researchrepository.wvu.edu/etd

\section{Recommended Citation}

Rhodes, Jessica M., "The West Virginia Uncovered eTrainer; creating an online multimedia training guide" (2009). Graduate Theses, Dissertations, and Problem Reports. 4519.

https://researchrepository.wvu.edu/etd/4519

This Thesis is protected by copyright and/or related rights. It has been brought to you by the The Research Repository @ WVU with permission from the rights-holder(s). You are free to use this Thesis in any way that is permitted by the copyright and related rights legislation that applies to your use. For other uses you must obtain permission from the rights-holder(s) directly, unless additional rights are indicated by a Creative Commons license in the record and/ or on the work itself. This Thesis has been accepted for inclusion in WVU Graduate Theses, Dissertations, and Problem Reports collection by an authorized administrator of The Research Repository @ WVU. For more information, please contact researchrepository@mail.wvu.edu. 
The West Virginia Uncovered eTrainer;

Creating an Online Multimedia Training Guide

Jessica M. Rhodes

A project submitted to the School of Journalism at West Virginia University in partial fulfillment of the requirements for the degree of

\author{
Master of Science \\ in \\ Journalism
}

\author{
John Temple, M.F.A., Chair \\ Bob Britten, Ph.D \\ George Esper, Ph.D. \\ Bill Kuykendall, M.A. \\ Mary Kay McFarland, M.A
}

Morgantown, West Virginia

2009

Keywords: Multimedia Journalism, West Virginia Uncovered,

Multimedia Training

Copyright 2009 Jessica M. Rhodes 


\title{
ABSTRACT \\ The West Virginia Uncovered eTrainer; Creating Content for an Online Training Guide
}

\author{
Jessica M. Rhodes
}

This professional project contains an external Web site, which serves as a multimedia journalism training guide for weekly rural newspapers in West Virginia. The training guide focuses on issues that many small rural newspapers face, including small staffs and limited budgets and resources. Small rural weekly newspapers in West Virginia serve as beacons of community journalism within their counties. Through the use of multimedia, they can enhance their Web sites to document the lives of those in their community in ways that are far more diverse than print journalism. This professional project also discusses the issues of social responsibility and the Internet as well as community journalism and the communitarian theory. 


\section{Acknowledgements}

I would first like to thank Dean Maryanne Reed and the faculty and staff at the West Virginia University Perley Isaac Reed School of Journalism for their support and guidance throughout my undergraduate and graduate years at West Virginia University. They provided me with the skills, knowledge and confidence to thrive as a journalist in the professional world.

A special thank you goes out to the members of my committee: Interim Associate Dean, John Temple; Professor George Esper; Assistant Professor and Visiting Shott Chair, Bill Kuykendall; Assistant Professor, Bob Britten and Multimedia Editor at the Charleston Gazette, Mary Kay McFarland. Each member of my committee served as a wonderful mentor and provided me with excellent resources and guidance that allowed this project to be possible.

I would also like to thank my parents and my family for all of their love and encouragement throughout my college career. They have always been there to support my educational endeavors and I appreciate all they have given me and for making it possible to pursue my goals.

Thank you also to my fiancé, BJ McGee for being a wonderful and loving support system and understanding of the demands and stress of graduate school. He has provided a great deal of love and encouragement and it has meant so much. 
Finally, I would like to thank each member of the West Virginia Uncovered Project: Tricia Fulks, Elaine McMillion, Kendal Montgomery, Megan Bowers, Steve Butera, Andy Smith, Leann Arthur, Erin Murray and Erin Woodell. They have each contributed so much to the West Virginia Uncovered project and deserve credit for a job well done. For those who attended the West Virginia Uncovered multimedia workshops, thank you for helping me document the training sessions so I could create the video tutorial. 


\section{TABLE OF CONTENTS}

ACKNOWLEDGMENTS iii

INTRODUCTION AND BACKGROUND 1

West Virginia Uncovered; $\quad 3$

Multimedia Journalism from the Mountains

LITERATURE REVIEW

Rural and Weekly Newspapers $\quad \mathbf{5}$

Multimedia Reporting and Training $\quad 6$

$\begin{array}{ll}\text { Social Responsibility Theory } & 8\end{array}$

Community Journalism and Communitarian Theory 9

THE eTrainer PROJECT

Research Statement $\quad 12$

Methodology 12

$\begin{array}{ll}\text { Survey } & 13\end{array}$

Survey Results $\quad 14$

Documenting the Training Sessions $\quad 17$

$\begin{array}{lr}\text { Creating Content for the eTrainer } & 18\end{array}$

$\begin{array}{ll}\text { Personal Interviews } & 20\end{array}$

Personal Interview Results $\quad 20$

The eTrainer Web site $\quad 21$

Optimizing the eTrainer Web site $\quad 22$

Project Timeline $\quad 26$

CONCLUSION $\quad 28$

$\begin{array}{ll}\text { Limitations } & \mathbf{2 8}\end{array}$

$\begin{array}{lr}\text { Future Research } & \mathbf{3 0}\end{array}$

$\begin{array}{ll}\text { RESOURCES } & 31\end{array}$

APPENDICES $\quad 33$

1. West Virginia Uncovered Participating Newspapers Questionnaire 33

2. Completed Newspaper Surveys 3

3. Exit Interview Questions $\quad 69$

4. Transcribed Exit Interviews

5. Examples of Final Cut Video Timeline $\quad \mathbf{8 5}$ 
6. eTrainer Design Sketch

86

7. West Virginia Uncovered Training Program and

Website eTrainer Web site

8. eTrainer Video Tutorials

$* *$

**eTrainer video tutorials are not located in this document, but can be found online at http://journalism.wvu.edu/slideshows/wv uncovered/ 


\section{LIST OF TABLES}

Table 1. Number of Reporters Who Contribute to Print and Web 15

Table 2. Number of Subscribers to a Newspapers Print and Web Edition $\mathbf{1 6}$

Table 3. Rankings of the Helpfulness of Training Resources 17 


\section{Introduction and Background}

Newspapers, in essence, are businesses, but they are not just for-profit companies, they are agents of change and public voices on public matters. Over the years, newspapers have adapted to new technologies. They have gone from typesetting by hand to pagination on a computer. They have used new technology to make their product better for the community (Sylvie \& Witherspoon, 2002). Even small rural West Virginia newspapers have changed with the times and begun taking their product online. For example, West Virginia weeklies such as The Pocahontas Times are online, offering those who live away the chance to catch up on local happenings. With the addition of a Web site to enhance their daily or weekly newspaper, a staff can reach an audience far beyond city limits. A resident of Marlinton, West Virginia can read The Pocahontas Times in their hometown or as far away as China, thanks to the newspaper's Web site. Wherever there is an Internet connection, there is a small-town American newspaper. But are most small rural newspapers taking advantage of this new medium? Are they capable of putting multimedia packages online? Do they have the training to enhance their online reporting and keep their readers actively involved and engaged in their newspaper? This professional project set out to create an online multimedia training guide focused on small rural weekly newspapers in West Virginia. The online training guide's premise is to offer newspapers with small staffs and limited resources access to information that will help them enhance their Web editions for little to no cost. But the West Virginia Uncovered eTrainer is not limited to small newspapers only. It is available, free of charge, to anyone interested in learning multimedia journalism skills.

The 21 st century has brought changes in the world of technology, and with those changes come new ways of communicating to the masses. Major news organizations such as $\mathrm{CNN}$ and 
MSNBC have Web sites, which they update with the latest national and international stories. In order to keep up with the trend toward a 24-hour news cycle, newspapers have created Web sites and hired online reporters. News organizations have also converged to offer more to their viewers and readers. For example, in Pittsburgh, WTAE, a local news station known as the Pittsburgh Channel and The Tribune-Review, a local newspaper, recently teamed up as partners in the media (Internet Broadcast Systems, Inc., 2008). Yet, outside of larger cities, many small newspapers seem to remain untouched by the converging journalism around them. In West Virginia, more than half of the rural weekly newspapers have Web sites, but on a much smaller scale than the Tribune-Review, or even the Charleston Daily Mail (West Virginia Press Association, 2008).

At the 2006 American Society of Newspaper Editors convention, Charles Pittman, senior vice president of Schurz Communications in South Bend, Ind., said about small newspapers, "Great things have always come from things that were once small. You are small and able to adapt more quickly to the realities of the market. You look to the future because you hear something coming down the tracks and you refuse to let it knock you off course." Newspapers in West Virginia are proving that point by taking a stand in the argument of offering free news content on the Web. In a personal exit interview for the West Virginia Uncovered training workshops and the eTrainer professional project, Charlie See, publisher of the Hampshire Review said: "We didn't buy into that back when everybody said 'give your content away.' In fact we were being criticized for not giving our content away. And now it's starting to swing back the other way. And we think we're in a position to make a little bit of money that way" (J. Rhodes, personal interview, March 30, 2009). 
There are 4,195 newspapers in the United States with main offices located outside of metropolitan areas. The audience of paid weekly newspapers is estimated at 10,146,089 and the total circulation of free weekly newspapers in the rural U.S. at 3,869,895 (Cross, Fielder, Tigas and Barnes, 2007). Of these 4,195 rural newspapers, 57 weekly newspapers are located in West Virginia (West Virginia Press Association, 2008). Of those 57 weekly newspapers, 40 have Web sites, yet many of these Web sites lack interactivity and multimedia elements. For example, The Parsons Advocate in Tucker County, West Virginia offers online subscribers content that is not found in their print edition, but it is limited to photo galleries (www.parsonsadvocate.com).

In West Virginia, in particular, there are many weekly newspapers that have built their reputations on bringing their communities local news on a weekly basis. In order to keep up with changes in technology, many of these newspapers need to engage their readers in more than one way. By adding multimedia and interactive elements to their Web site that they could not include in their print edition, community newspapers can interactively involve their readers. With the eTrainer training guide, they do not need to leave the comforts of their own newsroom to access the multimedia journalism skills presented during the West Virginia Uncovered workshops.

\section{West Virginia Uncovered; Multimedia Journalism from the Mountains project}

The West Virginia Uncovered eTrainer was created in conjunction with West Virginia Uncovered: Multimedia Journalism from the Mountains, a project hosted by the West Virginia University Perley Isaac Reed School of Journalism. WV Uncovered aims to teach students and West Virginia weekly newspapers various multimedia journalism techniques. The project was broken down into two focuses. The first part of the project allowed students the opportunity to cover stories in West Virginia using video, audio and photography. With the material they 
collected, the students created multimedia packages for the West Virginia Uncovered Web site, the county newspapers' print production and Web site, along with the Charleston Daily Mail in Charleston, West Virginia. The second part of the project aimed to teach the participating newspapers various multimedia journalism skills to help enhance their newspaper's Web site. The project is funded through a grant from the McCormick Foundation and will expand to the University of Kentucky in 2009. 


\section{Literature Review}

Even though there are organizations set up to support rural newspapers (e.g., The Institute for Rural Journalism) and newspapers looking to train in multimedia (e.g., The Knight New Media Center), I found little to no research about the use of multimedia at rural newspapers. Some research has been conducted on the training levels of mid-career journalists in rural newspaper settings, but there has been no specific focus on the need for multimedia training. Because of the void in the research for my project, I divided my initial research into several categories: rural and weekly newspapers, multimedia reporting and training and rural and community journalism.

\section{Rural and Weekly Newspapers}

The biggest challenges faced by rural newspapers are competition from a variety of sources, staffing issues, circulation declines and an uneducated population (Hansen and Givens, 2007). In April 2007, a study titled "A Survey of Training Methods and Needs at Rural Newspapers in the United States" was presented at the National Summit on Journalism in Rural America (Cross, et al., 2007). The study found that almost half of the newspapers surveyed offered training opportunities to employees and the most common form of specific training mentioned was in layout and design. In determining the background for their research, the authors found a void in the amount of research conducted on the mid-career training needs of rural newspapers. After their initial survey conducted in Central Appalachia resulted in only a few responses from newspapers, they decided to branch out and examine the needs of rural newspapers across the country. Many of these newspapers expressed a need and support for mid- 
career training, but several of the smaller newspapers with lower circulation ( 3,000 or less) could not afford to pay for their employees' attendance at conferences that focused on this particular type of training (Cross, et al., 2007).

\section{Multimedia Reporting and Training}

There are multimedia resources available to small newspapers such as crash courses on reporting and editing for the Web. They provide information and guides to using various types of software and equipment for editing audio and video, recording sounds and other types of multimedia gathering as well as inexpensive multimedia equipment and software (e.g., Briggs, 2007). A Poynter/News University Webinar cited equipment valuable for a multimedia newsroom and listed the equipment according to the best option for the price, ranging from "cost efficient" to "high-end" and gave the estimated totals for purchasing the cost-efficient equipment and the high-end equipment (Angelotti, 2007).

There are also blogs set up to teach others about using online journalism. Mindy's McAdam's blog "Teaching Online Journalism" is a posting of notes from her classroom and her observations of today's practices of online journalism (McAdams, 2009). In a series of posts which she titled "Reporter's Guide to Multimedia Proficiency," McAdams will discuss 15 methods and provide guidance for journalists who want to transform themselves into multimedia journalists. In the twelfth post of the series "Learn to Shoot Video," McAdams breaks down the broad topic of shooting video into smaller subcategories such as "looking for a story" and "shoot first, interviews later" (McAdams, 2009). McAdams also writes on a variety of multimedia topics. She has included posts about equipment and tips and tricks, which she learned throughout her experiences teaching and practicing multimedia journalism. 
There are also centers available to train mid-career journalists on how to use multimedia. The Knight New Media Center, for example, is an online tool for journalists who are attempting to enter the multimedia world. The center provides tutorials on how to use video equipment and software, and even how to use Web design software (Knight New Media Center, 2006).

Although there is not much research about using multimedia in a rural newspaper setting, rural newspapers are taking their productions online. In Kansas, a small weekly decided to take their newspaper online when they noticed that readers were turning to other sources for news. The 70-year-old Hesston Record asked readers to switch to a pay-based online version. Despite this move away from traditional printing, publisher Bob Latta believes that the Hesston Record is still the best and the only source for hometown news: "I think there's a lot of awareness of the Internet. A lot of people have computers and are comfortable with them, perhaps more than the normal town. I don't have anything to base that on, but it's my impression. It's also my hope" (Quill Magazine, 2003).

In Florida, Ronald Dupont Jr., former general manager of the St. Petersburg Times, left his job in 2003 to get "back to his rural roots," leaving the largest weekday newspaper in Florida to return as editor of the High Springs Herald, one of the state's smallest weekly newspapers with an estimated circulation of 5,000. In 2003 the High Spring Herald did not have a Web site (Sullivan, 2003). As of April 2008, the High Springs Herald has a Web site and Ronald Dupont Jr. is still the editor (High Springs Herald, 2008). "Being able to work with new ideas and news technology on a regular basis is an invigorating experience. I think back to the people who got to live through the start of TV, or the debut of electricity and then I think that I'll get to tell my grandchildren, 'I was there when the Internet started'” (Sullivan, 2003). 


\section{Social Responsibility Theory}

Although the Internet allows users overwhelming access to information, journalists, as part of their profession, must act with social responsibility. The media has an obligation to society, and they should be truthful, accurate, fair, objective and relevant, even when they are putting content online (McQuail, 2005). Every journalist - from the newsroom to the boardroom - must have a personal sense of ethics and responsibility - a moral compass (Kovach and Rosenstiel, 2001).

If ever a medium cried for the social responsibility theory as applied to journalists, it is the Internet. The Internet affords every user complete autonomy over personal communication, along with the power to disseminate content globally with a single click (Singer, 2006). Since there are no laws of journalism, or the Internet for that matter, a heavy burden rests on the ethics and judgment of the individual journalist and the individual organization where he or she works. Just because there are unreliable information sources on the Internet, it does not mean that a rural newspaper does not have to uphold journalistic standards. Journalists and organizations, regardless of the medium - Internet or print publication - must self-police (Kovach and Rosenstiel, 2001). This may be important to the journalist who has an individual need to preserve his or her occupational identity, but it is even more important to members of the public who have a compelling social need to differentiate between information that can be trusted and information that cannot (Singer, 2006).

The move to more reporting online inherently changes the notion of an information provider's responsibility to the audience in two potentially paradoxical ways, one accommodating an absence of accountability and the other accommodating much greater accountability than ever before. One may choose to publish content on the Internet however they 
please, with virtual impunity, but on the other hand, the two-way nature of Internet allows those reading content online to respond to it, making information production an interactive and readily accessible process in democratic societies. The public needs some means of differentiating between what is valuable to society as a whole and what is less so; otherwise the notion of a coherent public falls apart as each individual seeks out whatever seems most personally appealing at the moment (Singer, 2006).

Whether an audience member is conscious of it or not, when they choose a magazine, television station, newspaper or a Web site, they are choosing the authority of that organization and the judgment of the journalists who produce it. Journalists, regardless of medium, have an obligation to personal conscience (Kovach and Rosenstiel, 2001). A multimedia project must uphold the same journalist standards and practices. If a newspaper is going to put up a Web site with multimedia supplements to enhance their paper, they must uphold the same ethical practices as they do for their print piece. The Internet, regardless of its lack of rules and objectivity, is still a way for community members to get their news. News, in its entirety, must be fair and accurate.

\section{Community Journalism and the Communitarian Theory}

Along with the notion of social responsibility, small newspapers are also beacons of community journalism. In order for online news and multimedia to be successful, small newspapers must address the idea of community on the Internet, as many already do in their print editions. Editors and reporters are not only employees of the newspaper, but they are also residents and community members. For staff members, reporting and daily life tend to bleed together with so few people to cover. Many of the editors and reporters of the paper are interviewing neighbors and friends they see every day. Part of being a community journalist is 
being neighborly. In a small town there are only so many people to alienate until you've touched every household in the area (Lauterer, 2006).

The Internet can also be a valuable tool for community journalism. But for some, the Internet can also be seen as a way to retreat from a community. As James Carey said: "We apparently want a virtual community rather than a real one." He adds, "A virtual community is one that simulates or imitates qualities of a common life and a common culture without the physical or emotional geography of the small town, the centralized power of the state, or the exclusive dominion of the market." Carey also says, "To live in a community is to be aware that one's life depends on the uncoordinated decencies and actions of others; that life would constantly fail without the invisible contributions of others who with us inhabit the polity and the economy. In modem life interdependency only becomes apparent when the technology fails, the electric power goes off, the garbage workers go on strike and we are threatened by suffocation in our own filth" (Black, 1997, p. 5).

Carey's statement is relevant because it has to do with the idea that a community is more than one person. There are publics, or groups of people, that make of communities, such as the community of one and the virtual community, but it all comes back to the idea that we need other people to function. When something stops working, we can either fix it, or rely on someone else for help. The same goes for a newspaper. Multimedia has to happen within a community setting. It takes more than one person to make great multimedia, just like it takes more than one person to produce a community newspaper.

Carey also says that the word "community", beyond its sheer romance, does some heavyduty conceptual work. It also highlights the necessary interdependence of all human living and action and, philosophically, calls into question the spiritual individualism on which American 
culture is based while juxtaposing that individualism with the human need for community and culture as the ground for our functioning species (Black, 1997). The notion of community must satisfy; it must express and value interdependence without sacrificing individuality. This is the political work of a republican conception of community and, not so incidentally, a republican conception of the press (Black, 1997).

People want to be individuals, but at the same time, by nature, humans are social creatures. We yearn to connect with each other. Whether it's talking to a neighbor over a cup of tea, or turning the pages of a newspaper to find out the latest town happenings, or scrolling the pages of a Web site to keep up on current events to attend, community members want to know what is going on at all times. The word community might be the bane of a newspapers' existence, but as a small newspaper, it's impossible to get away from what community stands for. Regardless of who a reporter has been told owns their newspaper; the paper's true owner is the community. It doesn't matter where the paper is located as well, because the "middle of nowhere" is somebody else's universe (Lauterer, 2006). Every community has a story to tell and their story can be told to the world with the help of online multimedia. 


\section{The eTrainer Project}

\section{Research Statement}

Small rural weekly newspapers in West Virginia serve as beacons of community journalism within their counties. Through the use of multimedia, they can enhance their Web sites to document the lives of those in their community in ways that are far more diverse than print journalism. The West Virginia Uncovered eTrainer will serve as a tool for newspapers with limited resources and a smaller staff to learn how to create and implement multimedia on to their newspaper's Web site.

\section{Methodology}

In January 2009, the West Virginia Uncovered eTrainer professional project took a turn from its original path. The project was originally designed to be both a printed manual as well as a Web site. I decided that focusing on both mediums of distribution was too cumbersome and switched the focus of the project to an online training guide only. Another reason for the switch to an online manual online was due to the realization that I could reach a broader audience and avoid reinventing written training manuals that already focused on multimedia journalism. There are several training manual Web sites available such as Lynda.com, but there are little to no sites specifically focused on the needs of small newspapers. What makes this online training guide different from the others is its focus on the needs and concerns of small rural newspapers with small staffs and limited funds.

During my initial research for this project, I discovered that there are numerous multimedia training sites on the Internet. But, to the best of my knowledge, they do not contain information that specifically catered to small rural weekly newspapers. The Knight Digital 
Media Center offers multimedia workshops at the University of California Berkeley. They also host many of the workshop tutorials on their Web site. Because many of the rural newspapers in West Virginia operate far from big cities, there is not as much opportunity to attend large conferences and training camps on multimedia journalism. There is also a limited budget for new technology and the issues of smaller staffs.

Thanks to WV Uncovered project, I was granted unlimited access to all the training sessions held during the 2009 spring semester. The training sessions were broken down into three multimedia focuses of photography, audio and video. Each of the training sessions was documented and the material was broken down into smaller specialized segments for the eTrainer site. The newspapers participating in the training sessions were the Hampshire Review, The Parsons Advocate, The Pocahontas Times, The Nicholas Chronicle and The InterMountain.

The West Virginia Uncovered eTrainer has a strong emphasis in multimedia journalism and focuses on using inexpensive software and equipment for multimedia storytelling, gathering and editing video and audio as well as incorporating still photography and visual journalism elements into packaged stories for the Web. Users can log on and watch video tutorials, download PowerPoint presentations and PDFs and listen to audio files from the training workshops.

\section{Survey}

In order to discover information about the newspapers that would participate in the West Virginia Uncovered training workshops, a preliminary survey served as a method to quickly gather information. The survey was sent via e-mail to the editor/publisher of each newspaper participating in the training sessions. The editor/publishers were asked to fill out the survey and 
send it back before attending the first training session. Two newspapers sent the questionnaires back by the deadline and the rest were returned throughout the course of training sessions. Only five newspapers received the survey, four weekly papers and one daily newspaper (Appendix 2).

In order to find out information about staff and circulation, the newspapers' Web edition and their use of resources of multimedia training, the surveys contained both open-ended and close-ended questions. The open-ended questions were used as a means for the papers to discuss or expand on a topic presented. The close-ended questions were used as a method to gain information about the newspaper's staff and publication size (Appendix1).

\section{Survey Results}

After all of the surveys were returned, I analyzed the data and determined the value of the results based on their relevance to my research. For any of the misinterpreted survey questions, the data was thrown out and considered no longer valuable. Despite eliminating several questions from the preliminary survey, the majority of the data allowed a better understanding of the newspapers' current subscribers, their staff size and their overall goal of learning multimedia (Appendix 2).

In question 1, I asked each editor to list the number of employees, paid and non-paid on their staff and how many were contributing to the newspaper's Web edition. After analyzing the data, I was able to determine that the staffs of the papers were much smaller than anticipated. Although the staff sizes were small, the majority of the newspapers listed one-half or more of their reporters who contributed to the online site (Table 1). 
Table 1. Number of Reporters Who Contribute to Print and Web

\begin{tabular}{|l|r|r|r|}
\hline & \multicolumn{1}{|l|}{ Total Staff } & \multicolumn{1}{|l|}{ For Web } & For Print \\
\hline IM & 9.8 & 9.8 & 9.8 \\
\hline NC & 4 & 4 & 4 \\
\hline PA & 0.5 & 0 & 0.5 \\
\hline HR & 5 & 4 & 4.5 \\
\hline PT & 3 & 3 & 3 \\
\hline
\end{tabular}

\begin{tabular}{|l|r|r|r|}
\hline Totals & 22.3 & 20.8 & 21.8 \\
\hline Percentage & $100 \%$ & $\mathbf{9 3 \%}$ & $98 \%$ \\
\hline
\end{tabular}

From question 1, I also found that only one newspaper listed staff members who blog for their Web site. Questions 2, 3 and 4 did not provide much information because four out of five newspapers do not blog for the paper's Web edition. The Hampshire Review provided information about their blogging topics and identifying bloggers, but the overall data was eliminated due to the small amount of respondents.

Question 5 provided information about the ways that community members could contribute to each paper. From the data provided, most of the newspapers limited community submissions to letters to the editor and news photos. The Hampshire Review on the other hand, accepts submissions of videos, civic group blogs, business pages or blogs and government pages or blogs.

In question 6, I found that the number of people subscribing to the weekly newspapers' Web site is 100 or less. The total number of online subscribers to all four weekly newspapers is 240 and the total number of print subscriptions 19,650 . The one daily newspaper's Web edition subscribers total more than the total combined online subscribers of the weekly newspapers' Web editions at 5,000 (Table 2). 
Table 2. Number of Subscribers to a Newspapers Print and Web Edition

\begin{tabular}{|l|r|r|}
\hline & Print & Online \\
\hline IM & 11000 & 5000 \\
\hline NC & 8900 & 100 \\
\hline PA & 3800 & 30 \\
\hline HR & 7150 & 50 \\
\hline PT & 5350 & 60 \\
\hline
\end{tabular}

\begin{tabular}{|l|r|r|}
\hline Totals & 36200 & 5240 \\
\hline Percentage & $87 \%$ & $13 \%$ \\
\hline
\end{tabular}

In question 12 , the editors were asked to comment about tracking visitors to the newspapers' sites and what were the most popular places on the site. The answers provided an understanding of not only how the papers are using their sites, but also whether or not they are aware of what people want out of their Web edition. By knowing where readers are viewing content, the newspapers can make an assumption of the type of content their subscribers enjoy. When determining where to implement multimedia to increase traffic, a newspaper can look to the hits on their site for an idea of where the multimedia would best serve subscribers' needs.

In question 16, the survey asked where the newspapers were looking to for training resources. In order to rank the helpfulness of the sources, a Likert scale of one to seven was used. Seven was listed as the most helpful and one as the least helpful. From the responses mean of each source was found and the data revealed that journalism schools such as West Virginia University and the West Virginia Press Association were deemed the most helpful resources for multimedia training according to the newspapers (Table 3). 
Table 3. Rankings of the Helpfulness of Training Resources

\begin{tabular}{l}
\begin{tabular}{|l|r|r|r|r|r|r|r|}
\hline & WVPA & NNA & HigherEd & Online Tutorial & Paid Consult & Other & \\
\hline IM & 7 & 6 & 4 & 4 & 2 & 0 & \\
\hline NC & 7 & 4 & 5 & 6 & 2 & 0 & \\
\hline PA & 3 & 1 & 5 & 4 & 1 & 5 & Friends in Industry \\
\hline HR & 3 & 4 & 6 & 5 & 1 & 0 & \\
\hline PT & 7 & 1 & 7 & 0 & 0 & 0 & \\
\hline Average & $\mathbf{5 . 4}$ & $\mathbf{3 . 2}$ & $\mathbf{5 . 4}$ & $\mathbf{3 . 8}$ & 1.2 & 1 & \\
\hline
\end{tabular} \\
\hline
\end{tabular}

In conducting this survey, I wanted to learn about the views of editors toward multimedia training. Every editor deemed at least one of the multimedia topics listed in question 15 as a "high priority." Several listed all of the topics as a "high priority." In question 19, each of the editors answered positively toward helping the members of their staff learn multimedia journalism skills.

The answers to questions $7,10,11,14$, and 18 were disregarded from the survey results because of misinterpretation of the original question. Although the data was eliminated, the rest of the questions provided me with a picture of how each newspaper is operating in staff size, circulation size for print and the web, how they provide for their Web site, how they deem multimedia as a priority, and what are their goals for the West Virginia Uncovered training sessions. Although the survey questions were not directly related to using an online training guide, it allowed me to understand how to structure the eTrainer to suit the newspapers' needs.

\section{Documenting the training sessions}

Prior to the start of the training sessions, it was decided that each workshop would be documented and the material collected would be edited into tutorials, which would serve as the content for the West Virginia Uncovered eTrainer. The sessions were documented using video, 
audio and still photography. For each training session, a team of West Virginia Uncovered students helped to collect the raw content. Before the training sessions, I met with the presenters and discussed his or her plan for presenting material. From that discussion, a documentation outline was formulated for collecting and the duties were divided between the students attending the sessions in order to collect the material needed.

The first training session featured the topic of photography. For this particular section, it was pre-planned that any demonstrations would be videotaped and any segments with a PowerPoint presentation would be audio only. The audio and video sessions were pre-planned in a similar fashion so an overall idea of what sections would need a particular documentation was in place. There was also room for improvising on the fly if needed. Although each session had a pre-planned documentation method, there were some cases where the pre-determined method was not always used. For example, if it was pre-determined that all demonstrations would be documented with video and the situation deemed better for still photos than we would switch to still photography or use both methods to document the demonstration. The documentation plan provided an outline, but it was adjusted as needed.

\section{Creating content and the eTrainer site}

After each of the training sessions, a plan was developed for how the information gathered would be edited for the eTrainer. For each section of the eTrainer, the number of videos, audio files and PowerPoint presentations was determined and an editing plan was developed. Once a plan for the material was complete, the raw material was broken down and edited to produce the final video and audio files. Breaking down the PowerPoint files slide by slide and laying them over audio tracks created several of the videos. The videos presented by 
Mary Kay McFarland for the video training session were broken down into smaller segments to match her recorded audio. Each of videos created for the eTrainer are under ten minutes long and featured specific topics such as video cameras, video equipment segmenting video, shooting basics, etc.

In the video section in particular, the videos were broken down in two different manners. Several of the videos are about equipment, so a mixture of the presented slides, photographs and video of her equipment as well as West Virginia Uncovered equipment were used to create a multimedia package that shows the equipment as it is mentioned in the recorded audio (Appendix 5).

Mary Kay McFarland also created her own videos for the session, which she used to show examples of raw footage shot by the staff members at the Charleston Gazette. In order to use her video for tutorials, her original files were broken down and edited in Final Cut Pro to match the audio recorded during her presentation. To create the audio files, Audacity, a free audio editing software program was used. Final Cut Pro was also used to edit some audio files.

Once the first set of training videos, audio files and PowerPoint presentations were ready for implementation into the eTrainer site, a design meeting was held to determine the look of the Web site that would house the tutorials (Appendix 6). The meeting was held with WV Uncovered Webmaster Timothy Broadwater, photography and audio workshop presenter Bill Kuykendall, project director John Temple and myself. Once the design was decided (Appendix 6), Timothy Broadwater developed and created the final eTrainer site. Broadwater also uploaded completed files to the eTrainer site. 


\section{Personal interviews}

During the final training session, the editors and publishers of the four weekly newspapers individually answered questions about their experience throughout the project. They were asked questions specifically about the training session (Appendix 3) and those questions were followed by another student's questions about the overall experience of working with WV Uncovered. The exit interviews were transcribed and used to find common themes (Appendix 4).

The personal one-on-one interviews featured unstructured questions allowing opportunity to determine the next question due to the direction taken by the interviewee. Although unstructured questions were used, a predetermined list of questions was developed as a guideline for the interview. Not all the questions were asked during each interview. Questions were also left out because of time constraints. The interviewees were pulled out during the lunch break of final training session, so to keep from running over into the next segment of the session, the interviews were limited in time. Senior journalism student Elaine McMillion conducted the final personal interview with Nicholas Chronicle editor Matt Yeager. Because of my participation in the final segment of the training session, I was not able to interview Yeager. She was provided with the predetermined list of questions for the interview.

\section{Personal Interview Results}

From the transcribed personal interviews, I was able to determine that the newspaper editors were pleased with the West Virginia Uncovered training sessions and that they would like to continue in the future. One of the most valuable findings in the exit interviews was the editors' response to the question of using an online training guide. Each of the editors seemed hesitant, claiming he or she would rather attend a group training session, which allowed interaction with 
the audience and speaker. None of the editors were opposed to trying the online training guide, but many stressed that they prefer the classroom setting instead.

Also from the personal exit interviews, I was able to determine future training tutorials that could be created for the eTrainer. In one interview, an editor mentioned that they would like to see training on the basics of writing and reporting and another mentioned that they would like to see a session offered on how to obtain funding for multimedia equipment.

\section{The eTrainer Web site}

The West Virginia Uncovered Web site's homepage features a large Google Map on the left and a navigation bar on the right. Within the navigation bar are several sections of the site where users can find the multimedia stories by county. In the navigation bar, he or she can also find a link for the West Virginia Uncovered Training Program (http://wvuncovered.wvu.edu/ training_program) By clicking on the Training Program link in the navigation bar, he or she is taken to a default page before entering the eTrainer portal. On the Training Program page, users will see a large "West Virginia Uncovered eTrainer enter here" button. The button is one of multiple ways to access the eTrainer page. The other links are located in the text to the right of the button.

Once a user enters the eTrainer portal, a video introduction begins and it features John Temple, the West Virginia Uncovered program director, discussing the importance of the training workshops and the eTrainer Web site (http://journalism.wvu.edu/slideshows/wv uncovered). Participants in the eTrainer portal can either watch the introduction video or immediately click on the materials in the right-hand navigation bar. When a user clicks on an item in the navigation bar, it will load as a PowerPoint presentation, a video, PDF, or audio file. 
If the item is a PDF or PowerPoint file, the user must double click the icon that appears to the left and the item will download to the computer's desktop. If the item is a video or audio file, it will open on the left and begin to play. Each video, audio file, PowerPoint and PDF has its own description, which is located under the loaded item.

\section{Optimizing the eTrainer Web site}

In March, the eTrainer Web site was created with a preliminary design in order to get the content on to the Web in a timely manner. Now that all of the content is complete, the eTrainer could benefit from an optimized Web site design. The current design does not allow for much usability and instead has small windows to view videos and an ineffective method for accessing

PDFs and PowerPoint files. The content navigation bar also takes up a great deal of the site's real estate.

In order to make the eTrainer design effective, and to make it more appealing to newspaper editors who may seem hesitant about an online training site, one must consider the user. First of all, the ideal user of the eTrainer Web site would be interested in learning multimedia journalism skills. Another user of the site would be the editors and staff members of the weekly newspapers who participated in the West Virginia Uncovered training workshops. Because the users of the site would be accessing the information to help enhance their Web sites, the eTrainer should be reflective of a successful way to incorporate multimedia. Examples of already existing multimedia sites include, Mediastorm (www.mediastorm.org), and "One in 8 Million,” a multimedia feature by the New York Times (http://nytimes.com/packages/html Inyregion/1-in-8-million/index.html?ref=multimedia). Elements from their Web site could be 
incorporated into the eTrainer's site to give it more of a multimedia feature story look and appeal.

What makes these sites so great is that they are not only esthetically pleasing to look at, but they are also useable. One of the biggest concerns among usability professionals is the time it takes users to scan the page for the information they want, be it a piece of content, a link to another page, or a form field. The design should not be a hindrance; it should act as a conduit between the user and the information (Beaird, 2007).

When designing a Web site, usability must be taken into account. Usability focuses on functionality, the effective presentation of information, and efficiency (Beaird, 2007). The usability of the eTrainer site should focus on designing the content so that it is both easy to navigate through, but also so that the user will not find it a hindrance that the video window is too small, or that they can not see the description in order to understand what the video is about. The Web site should also provide a link back to the original site, so that if necessary, a user can either retrace their steps or go back to the original site to view other content. In this case, the link should go back to the West Virginia Uncovered homepage.

I believe that in order to draw a user's attention into the eTrainer site, the emphasis of the design should focus on the video tutorials. Rather than making the navigation bar and the viewer symmetrical to each other, the emphasis should lie in the videos and then everything on the page can be built around the videos. The bulk of the user's interest will lie in the information presented in each video. The New York Times "One in 8 Million" puts the emphasis on their video pieces and your eye is drawn to that section of the page and then you look around to find out what the video is about. The video is placed as the page's focal point. A focal point is anything on the page that draws the viewer's eye, rather than just feeling like a part of the page 
as a whole or blending in with its surroundings (Beaird, 2007).

Jakob Nielsen also stresses that an import aspect of Web site should be its accessibility, and the first guideline for accessibility is simplicity (Yank, 2002). A design should have a simple clean layout that allows the user to find what they are looking for quickly. The current eTrainer design may be confusing to a user who was not present at the West Virginia Uncovered training sessions and does not understand how the information is organized. The current navigation bar, despite its large size is not easy to navigate. The set-up for the headings does not make sense for the content that appears under that particular topic. The video tutorials are not easily identifiable and are instead mixed in with the PDFs and PowerPoint files. In future, the PowerPoints will be uploaded to the site as movie file so that a user can watch them in the eTrainer instead of downloading them to their computer desktop. In order to make the movie files separate from the PDFs, the PDFs could be located in an appendix to the site.

Another important aspect of the eTrainer Web site should be its background color. The eTrainer's background is a blue color that is associated with many West Virginia University Web sites. Using blue as a background may say that the site has openness, intelligence, and faith. Physiologically, blue has been found to calm people down, but it sometimes seen as a symbol of bad luck and trouble. If it was possible to design outside of the color scheme for West Virginia University sites, I would chose a background of green because it holds more value to the content in the eTrainer. The eTrainer site is in conjunction with West Virginia Uncovered, which features multimedia stories about the state of West Virginia. When I think about West Virginia, I think of the great outdoors, lots of trees, hiking, hunting, backpacking and great scenery. Although, the eTrainer is not focused on nature, it is focused on small rural newspapers and those newspapers are often located in areas with a great deal of scenery that draw in tourists. 
Green is associated with nature. It is a very soothing color that symbolizes growth, freshness, and hope. It's much easier on the eyes, and far less active, than yellow, orange, or red (Beaird, 2007). Although, green may be the more optimal color for the eTrainer, unfortunately, blue may be a better option to keep conformity with other West Virginia University Web sites.

If I were to design the new eTrainer Web site, I would take cues from "One in 8 million" and put the focus of the site on the videos, with the navigation of all the additional videos in a scrolling block underneath the videos. I would make the background a lighter shade of green in order to make the videos pop against the background. As you scroll through the navigation bar, the videos will also scroll across the screen to the left. I would place the descriptions and title of the piece under the video and above the navigation bar. As you scroll through the navigation bar and the video appears in the main frame, it will play an audio clip and show a freeze frame from the video. When you click on a video in the navigation bar or on the large video above it will load and begin to play.

A user's broadband access (cable, DSL, satellite or dial-up), will determine the amount of time it takes a video to load in the window. Because many of the newspaper staff members who will view this site are located in rural areas with limited access to the Internet, a lower broadband version of the site may need to be created with smaller videos. At my house, I have DSL, and I was able to access the New York Times' site without much wait time to download the videos. However, trying to view larger videos with dial-up access would cause a longer download time.

Once the new design is created, it will benefit from testing. In the future, the West Virginia Uncovered Project could test its entire site to find out how users click around to find information. Focus groups could be conducted to find out how users feel about how the content is arranged on the eTrainer site, but that is an entirely new graduate student project and due to 
time limitations, I was not able to conduct a similar test for my project.

\section{Project Timeline}

The research stage of the professional project began in spring 2008 and was carried out in Morgantown, West Virginia. The multimedia training sessions for the West Virginia Uncovered Project were held in Romney and Elkins, West Virginia. The training sessions began on February 13, 2009 and ended on March 30, 2009. As part of the grant from the McCormick Foundation, each of the participating newspapers received an invitation to attend the training sessions held by the West Virginia Uncovered project and each newspaper was given a Flip Mino camcorder to begin recording video for their sites. The training sessions featured multimedia and Web design experts Bill Kuykendall, Mary Kay McFarland and Tim Broadwater. The West Virginia weekly newspapers invited to seminar were the Hampshire Review, The Parsons Advocate, The Nicholas Chronicle and The Pocahontas Times. The InterMountain, a daily newspaper in Randolph County was also invited because they graciously helped to host the training sessions located in Elkins.

Development of the eTrainer portion of the project began in December 2008 and ended in April 2009. Prior to the training sessions in February, each of the participating newspapers received the West Virginia Uncovered Participating Newspaper Questionnaire (Appendix 1). In February, with the help of several West Virginia Uncovered project members, the training sessions were documented using video, audio and photographs. From February to April, the eTrainer content was collected, edited and created.

In early March 2009, the eTrainer Web site went live. On March 30, 2009, the final training session was held in Elkins, West Virginia. At that session, each editor of the weekly 
newspapers participated in a short exit interview for the training manual and the overall project. In April, the project was finalized and the last set of tutorials went live on the West Virginia Uncovered eTrainer Web site. 


\section{Conclusion}

When I set out to create this project, I started with the goal of creating a multimedia training manual that was designed specifically for the needs and wants of small rural newspapers in West Virginia. As the project developed, it became more apparent that the need for an online training site with the same information would benefit a greater audience. With an online training guide, I could still achieve my goal of helping newspapers with limited resources and small staffs to access information about multimedia training in one centralized location. Now that the site has gone live, it will be available to the newspapers that attended the training sessions as well as anybody looking to find information about incorporating multimedia on a limited budget.

I am pleased with the end result of the tutorials that were created during this project and I hope that future research can continue from where I left off. I found that throughout this entire process, my confidence as a multimedia journalist continued to grow and I became more passionate about this medium. Because of my increased passion, the desire to share what I learn with others became even greater. I hope that the West Virginia Uncovered eTrainer will continue to grow and benefit others, and I hope that it will reach audience not just in West Virginia, but also around the world. Journalism is continuing to change and small rural newspapers around the world can take the lessons from this online training guide and use them to enhance the stories of their communities via the Internet.

\section{Limitations}

As with many projects, the West Virginia eTrainer faced a few obstacles along the way. Prior to the start of the multimedia training sessions, it was thought that the West Virginia 
Uncovered Project would visit each individual newspaper and conduct the training sessions. In a discussion with the newspapers prior to the start of the training workshops, a newspaper editor suggested to Bill Kuykendall that it might be easier to pick a central location of Elkins, West Virginia to hold the sessions. Several of the newspapers agreed to meet in Elkins, but because of the distance and other constraints, the editor of Hampshire Review opted to have the West Virginia Project visit Romney for the first two sessions and then they joined the group in Elkins for the final session.

Because of the limited about of time for each session, I was not able to conduct case studies with each paper as previously planned. Also, because the project opted not to visit the individual papers, there was less time to speak with staff members and editors about their progress on multimedia. However, this probably worked out in the end, because I found out in the personal interviews that not many of the papers had made headway on incorporating multimedia into their sites. They were also struggling to find money to buy equipment to start their multimedia operations. Because these newspapers are so small in staff size, many of their reporters are pulling double-duty as writers, photographers and now videographers, so the papers have been slow to incorporate multimedia in their weekly operations.

Due to the limited amount of time to create the training manual and conduct research, there are several research methods I would have applied to this project if time allowed. The first method would be to conduct the exit interviews later in the summer after the newspaper staff members had an opportunity to create a multimedia package and incorporate the new medium into the newspaper's Web edition. I would also like to track the number of people who are visiting the eTrainer site and create a demographic map of viewers. Finally, I would conduct a 
focus group with each of the newspapers that took part in the training sessions and ask them to look over the eTrainer and give their feedback on its usability and content.

\section{Future Research}

This project has the potential to continue in many different directions from my completed project. In the future, I would like to see a graduate student with an advertising background, create a section of online training materials focused on how these newspapers can build revenue through online advertisements and help them to create a business model. I also feel training materials on basic writing and editing skills could be added to the eTrainer. The newspaper editors also mentioned in their exit interviews that a refresher on how to write an effective story and basic journalistic skills would be a training session that they would like to see in the future.

I think the next step from my research, and possibly another future graduate student professional project is to continue the training manual by adding additional content, but also after the site is redesigned, finding effectiveness of the material presented. Are people accessing the content and applying it to their daily reporting? Are there any success stories from the Web site? The student could set up a way for people to send comments and a way for users to possibly receive a survey after they have logged on to the site. There are endless possibilities for the future of the West Virginia Uncovered eTrainer. The most exciting part of completing my portion of the eTrainer is that it can only grow from here. I hope that someone can pick up where I left off and continue to help rural newspapers build their businesses. 


\section{Resources}

Angelotti, E. (2008). a. Multimedia Tools: Your 2008 Shopping List: What Your Newsroom Needs retrieved on March 10, 2008 from www.newsu.org

Angelotti, E. (2008). b. Multimedia Tools: Your 2008 Shopping List retrieved on March 10, 2008 from www.newsu.org

Beaird, Jason (2007). The Principles of Beautiful Web Design. Australia: SitePoint Pty. Ltd.

Black, J. (1997). Mixed News; the Public/Civic/Communitarian Journalism Debate. Mahwah, New Jersey: Lawrence Erlbaum Associates, Inc.

Briggs, M. (2007). Journalism 2.0 How to Survive and Thrive, a Digital Literacy Guide for the Information Age. Knight Publishing

Contact Us (2008), High Springs Herald, retrieved on April 11, 2008 from http://www.highspringsherald.com/contact_us/

Cross, A., Fielder, V., Tigas, C. N. \& Barnes, B. (2007). A Survey of Training Backgrounds and Needs at Rural Newspapers in the United States retrieved from http://www.uky.edu/CommInfoStudies/IRJCI/summitoverview.html

Hansen, E.K. \& Givens, D. T. (2007). Threats to Rural Newspapers, retrieved on March 11, 2008 from http://www.uky.edu/CommInfoStudies/IRJCI/summitoverview.html

Kovach B. \& Rosenstiel T. (2001). The Elements of Journalism: What Newspeople Should Know and the Public Should Expect. New York, NY: Three Rivers Press

Lauterer, J. (2006). Community Journalism; Relentlessly Local. The University of North Carolina Press

McAdams M. (2009). RGMP 12: Learn to shoot video, retrieved on April 14, 2009 from http://mindymcadams.com/tojou/2009/rgmp-12-learn-to-shoot-video/

McAdams M. (2009). Reporter's guide to multimedia proficiency (RGMP 1), retrieved on April 14, 2009 from http://mindymcadams.com/tojou/2009/reporters-guide-tomultimedia-proficiency-part-1/

McQuail, D. (2005). McQuail's Communication Theory $\left(5^{\text {th }} \mathrm{ed}.\right)$, SAGE Publications, 170-172

“Multimedia Training” (2006). Knight New Media Center, retrieved on April 17, 2008 from http://www.knightdigitalmediacenter.org/multimedia_training/ 
Partners (2008). Internet Broadcast Systems, Inc. retrieved on April 28, 2008 from http://www.thepittsburghchannel.com/index.html

Pitman, C. (2006). Small newspapers will lead the way as industry adapts, retrieved on April 28, 2008 from http://www.ruraljournalism.org/

Singer, Jane B. (2006). The Socially Responsibility Existentialist, A Normative emphasis for Journalists in a New Media Environment, Journalism Studies, Vol 2, No. 1

Society of Professional Journalism (2003). Small Paper Redefines Itself Online, Quill Magazine, 7

Sullivan, C. (2003, July 14). Web Ace Gets Back to His Rural Roots Editor and Publisher Magazine

Sylvie, G. \& Witherspoon, P. (2002). Time, Change and the American Newspaper, Mahwah, New Jersey: Lawrence Erlbaum Associates, Inc.

"West Virginia Weekly Newspapers Online" (2008). West Virginia Press Association, retrieved on April 28, 2008 from http://www.wvpress.org/newsonline.asp

Wimmer, R. \& Dominick J. (1991). Mass Media Research: An Introduction (3 ${ }^{\text {rd }}$ ed.). Belmont, California: Wadsworth Inc.

Yank, Kevin (2002), Interview-Jakob Nielsen, Ph.D. retrieved on April 25, 2009 from http://www.sitepoint.com/article/interview-jakob-nielsen-ph-d/ 


\section{Appendices}

\section{Appendix 1.}

\section{West Virginia Uncovered Participating Newspapers Questionnaire}

Newspaper Name:

Date:

Your name:

Job title:

1. Please enter the following information: Note FTE = full time equivalent, i.e. one FTE adds up to 40 hours/wk; Personal = blogs on a wide variety of topics chosen at the discretion of the blogger; Topical $=$ blog(s) devoted to specific topics such as hunting, the economy, home improvement, etc.

\begin{tabular}{|c|c|c|c|c|c|c|c|}
\hline \multirow[t]{2}{*}{ Staff positions } & \multirow[t]{2}{*}{ Total Staff } & \multirow{2}{*}{$\begin{array}{l}\text { Total } 100 \% \\
\text { FTE paid } \\
\text { staff }\end{array}$} & \multirow{2}{*}{$\begin{array}{l}\text { Total unpaid } \\
\text { contributors }\end{array}$} & \multirow{2}{*}{$\begin{array}{l}\text { How many } \\
\text { produce } \\
\text { content for } \\
\text { the web? }\end{array}$} & \multirow{2}{*}{$\begin{array}{l}\text { How many } \\
\text { produce } \\
\text { content for } \\
\text { print? }\end{array}$} & \multicolumn{2}{|c|}{ How many blog? } \\
\hline & & & & & & Personal & Topical \\
\hline Reporters & & & & & & & \\
\hline Photographers & & & & & & & \\
\hline Editors & & & & & & & \\
\hline $\begin{array}{l}\text { Advertising/ } \\
\text { Sales }\end{array}$ & & & & & & & \\
\hline Columnists & & & & & & & \\
\hline $\begin{array}{l}\text { Community } \\
\text { contributors }\end{array}$ & & & & & & & \\
\hline
\end{tabular}

2. What topics are covered by blogs in your online edition?

3. How do you decide what topics to blog about?

4. How do you identify prospective bloggers? 
5. How can community members contribute to your newspaper? Check all that apply.

\begin{tabular}{|l|l|l|l|l|l|l|l|l|l|}
\hline & $\begin{array}{l}\text { Letters to } \\
\text { editor }\end{array}$ & $\begin{array}{l}\text { Op Ed } \\
\text { columns }\end{array}$ & $\begin{array}{l}\text { News } \\
\text { photos }\end{array}$ & $\begin{array}{l}\text { Audi } \\
\text { o } \\
\text { clips }\end{array}$ & $\begin{array}{l}\text { Video } \\
\mathrm{s}\end{array}$ & $\begin{array}{l}\text { Personal } \\
\text { blogs }\end{array}$ & $\begin{array}{l}\text { Civic } \\
\text { group blog }\end{array}$ & $\begin{array}{l}\text { Business } \\
\text { page or } \\
\text { blog }\end{array}$ & $\begin{array}{l}\text { Government } \\
\text { page or blog }\end{array}$ \\
\hline Print & & & & & & & & & \\
\hline Web & & & & & & & & \\
\hline
\end{tabular}

6. Please answer the following to the best of your knowledge:

\begin{tabular}{|l|l|}
\hline How many readers subscribe to your print edition? & \\
\hline Your online edition? & \\
\hline Both? & \\
\hline
\end{tabular}

7. When it comes to uploading content to your website, how much do you repurpose from the print edition?

\begin{tabular}{|l|l|l|l|l|l|l|}
\hline $\begin{array}{l}\text { Amount } \\
\text { repurposed: }\end{array}$ & News & Sports & Features & Obits & $\begin{array}{l}\text { Calendar of } \\
\text { events }\end{array}$ & Other \\
\hline $100 \%$ & & & & & & \\
\hline $75 \%$ to $99 \%$ & & & & & & \\
\hline $50 \%$ to $75 \%$ & & & & & & \\
\hline Less thatn $50 \%$ & & & & & & \\
\hline None & & & & & & \\
\hline
\end{tabular}

8. Does your web edition contain content that does not appear in your print edition?

Yes No

If yes, please describe this content and how it differs from print content, and explain why it appears only online. 
9. Do you use your print edition to attract readers to your website? If yes, please explain how.

10. Approximately what percentage of total corporate revenues is generated by:

\begin{tabular}{|l|l|l|l|l|l|l|}
\hline \multicolumn{2}{|l|}{ Subscriptions } & \multicolumn{2}{|l|}{ Advertising } & $\begin{array}{l}\text { Sales of } \\
\text { photos }\end{array}$ & $\begin{array}{l}\text { Web design } \\
\text { and/or hosting }\end{array}$ & Other \\
\hline Print & Web & Print & Web & & & \\
\hline & & & & & & \\
\hline
\end{tabular}

11. Approximately what percentage of total corporate revenues would you like to generate in each of these areas?

\begin{tabular}{|l|l|l|l|l|l|l|}
\hline \multicolumn{2}{|l|}{ Subscriptions } & \multicolumn{2}{|l|}{ Advertising } & $\begin{array}{l}\text { Sales of } \\
\text { photos }\end{array}$ & $\begin{array}{l}\text { Web design } \\
\text { and/or hosting }\end{array}$ & Other \\
\hline Print & Web & Print & Web & & & \\
\hline & & & & & & \\
\hline
\end{tabular}

12. If you can track the number of hits received by your website, can you say which areas attract the greatest attention? Please explain. 
13. How do members of your community access the Internet for all purposes, not just to read your publication? Are most of them active users who depend on it for a wide range of social, civic, educational and business purposes, or does the community pretty much reflect the national average in terms of age, gender, economic status, or do you think your community lags behind other communities. Please comment.

14. How do subscribers access your web edition? Please enter a percentage number that you think best describes the current situation. All should total 100\%.

\begin{tabular}{|l|l|l|l|}
\hline Dial-up service & High-speed cable & DSL service & Satellite \\
\hline & & & \\
\hline
\end{tabular}

15. How important is it that your staff members learn to produce multimedia content for your publication? Please respond by placing the appropriate letter in the boxes beneath each medium.

"H" - High priority "M" — Moderately High priority "L" — Low priority

\begin{tabular}{|l|l|l|l|l|}
\hline Still photography & Audio podcasting & $\begin{array}{l}\text { Video shooting \& } \\
\text { editing }\end{array}$ & Other & Other \\
\hline & & & & \\
\hline
\end{tabular}


16. How have the following sources of multimedia skills training served you and your staff. Please circle the number on each of the scales below that best expresses your opinion, \#1 being least helpful and \#7 being most helpful. Circle NA if this source has played no factor in your professional development.

1. West Virginia Press Association

$\begin{array}{llllllll}1 & 2 & 3 & 4 & 5 & 6 & 7 & \mathrm{NA}\end{array}$

Least

Most

2. National Newspaper Association

\begin{tabular}{llllllll}
1 & 2 & 3 & 4 & 5 & 6 & 7 & $\mathrm{NA}$ \\
\hline
\end{tabular}

Least Most

3. Higher education, such as WVU School of Journalism

$\begin{array}{cccccccc}1 & 2 & 3 & 4 & 5 & 6 & 7 & \text { NA } \\ \text { Least } & & & & & & \text { Most } & \end{array}$

4. Online tutorial sites such as Lynda.com

$\begin{array}{llllllll}1 & 2 & 3 & 4 & 5 & 6 & 7 & \text { NA }\end{array}$

Least Most

5. Paid consultants

$\begin{array}{llllllll}1 & 2 & 3 & 4 & 5 & 6 & 7 & \text { NA }\end{array}$

Least Most

6. Other

$\begin{array}{llllllll}1 & 2 & 3 & 4 & 5 & 6 & 7 & \text { NA }\end{array}$

Least

Most 
17. Please explain how you hope to benefit from the WV Uncovered multimedia workshop initiative.

18. How important is the Internet to your staff as an editorial research tool?

$\begin{array}{lllllll}1 & 2 & 3 & 4 & 5 & 6 & 7\end{array}$

Very important Not important

a. If it plays a significant role in research, please describe the types of sites educational, governmental, corporate, special interests, personal sites, etc. - - that you find most useful.

b. If the Internet does not play a role in editorial research, what are your primary methods for researching stories?

19. How, besides participating in the WV Uncovered project, do you intend to help your staff acquire new multimedia skills and integrate multimedia content into your publication? 


\section{Appendix 2. Completed West Virginia Uncovered Participating Newspapers Questionnaire}

Newspaper Name: _ The Inter-Mountain, Elkins, WV Date: 3/25/09

Your name: Don Smith Job title: General Manager (former editor)

1. Please enter the following information: Note FTE = full time equivalent, i.e. one FTE adds up to 40 hours/wk; Personal = blogs on a wide variety of topics chosen at the discretion of the blogger; Topical $=$ blog(s) devoted to specific topics such as hunting, the economy, home improvement, etc.

\begin{tabular}{|c|c|c|c|c|c|c|c|}
\hline \multirow[t]{2}{*}{ Staff positions } & \multirow[t]{2}{*}{ Total Staff } & \multirow{2}{*}{$\begin{array}{l}\text { Total } 100 \% \\
\text { FTE paid } \\
\text { staff }\end{array}$} & \multirow{2}{*}{$\begin{array}{l}\text { Total unpaid } \\
\text { contributors }\end{array}$} & \multirow{2}{*}{$\begin{array}{l}\text { How many } \\
\text { produce } \\
\text { content for } \\
\text { the web? }\end{array}$} & \multirow{2}{*}{$\begin{array}{l}\text { How many } \\
\text { produce } \\
\text { content for } \\
\text { print? }\end{array}$} & \multicolumn{2}{|c|}{ How many blog? } \\
\hline & & & & & & Personal & Topical \\
\hline Reporters & 9.8 & 9 & 0 & 9.8 & 9.8 & 0 & 0 \\
\hline Photographers & 2 & 1 & 0 & 2 & 2 & 0 & 0 \\
\hline Editors & 3 & 3 & 0 & 3 & 3 & 0 & 0 \\
\hline $\begin{array}{l}\text { Advertising/ } \\
\text { Sales }\end{array}$ & 7 & 7 & 0 & 7 & 7 & 0 & 0 \\
\hline Columnists & 3 & & 0 & 3 & 3 & 0 & 0 \\
\hline $\begin{array}{l}\text { Community } \\
\text { contributors }\end{array}$ & 3 & & 0 & 3 & 3 & 0 & 0 \\
\hline
\end{tabular}

2. What topics are covered by blogs in your online edition?

$\mathrm{n} / \mathrm{a}$

3. How do you decide what topics to blog about?

$\mathrm{n} / \mathrm{a}$

4. How do you identify prospective bloggers?

$\mathrm{n} / \mathrm{a}$ 
5. How can community members contribute to your newspaper? Check all that apply.

\begin{tabular}{|l|l|l|l|l|l|l|l|l|l|}
\hline & $\begin{array}{l}\text { Letters to } \\
\text { editor }\end{array}$ & $\begin{array}{l}\text { Op Ed } \\
\text { columns }\end{array}$ & $\begin{array}{l}\text { News } \\
\text { photos }\end{array}$ & $\begin{array}{l}\text { Audi } \\
\mathrm{o} \\
\text { clips }\end{array}$ & $\begin{array}{l}\text { Video } \\
\mathrm{s}\end{array}$ & $\begin{array}{l}\text { Personal } \\
\text { blogs }\end{array}$ & $\begin{array}{l}\text { Civic } \\
\text { group blog }\end{array}$ & $\begin{array}{l}\text { Business } \\
\text { page or } \\
\text { blog }\end{array}$ & $\begin{array}{l}\text { Government } \\
\text { page or blog }\end{array}$ \\
\hline Print & $\mathrm{X}$ & $\mathrm{x}$ & $\mathrm{x}$ & & & & & & \\
\hline Web & $\mathrm{X}$ & $\mathrm{x}$ & $\mathrm{x}$ & & & & & & \\
\hline
\end{tabular}

6. Please answer the following to the best of your knowledge:

\begin{tabular}{|l|l|}
\hline How many readers subscribe to your print edition? & 11,000 daily \\
\hline Your online edition? & 5,000 daily \\
\hline Both? (We are uncertain about the overlap) & 16,000 daily \\
\hline
\end{tabular}

7. When it comes to uploading content to your website, how much do you repurpose from the print edition?

\begin{tabular}{|l|l|l|l|l|l|l|}
\hline $\begin{array}{l}\text { Amount } \\
\text { repurposed: }\end{array}$ & News & Sports & Features & Obits & $\begin{array}{l}\text { Calendar of } \\
\text { events }\end{array}$ & Other \\
\hline $100 \%$ & $\mathrm{x}$ & $\mathrm{x}$ & & $\mathrm{x}$ & $\mathrm{x}$ & $\mathrm{x}$ \\
\hline $75 \%$ to $99 \%$ & & & $\mathrm{x}$ & & & \\
\hline $50 \%$ to $75 \%$ & & & & & & \\
\hline Less thatn $50 \%$ & & & & & & \\
\hline None & & & & & & \\
\hline
\end{tabular}

8. Does your web edition contain content that does not appear in your print edition?

Yes No

If yes, please describe this content and how it differs from print content, and explain why it appears only online.

We place breaking news, alerts and other items that miss our print deadline.

9. Do you use your print edition to attract readers to your website? If yes, please explain how.

Yes. We promote the website in each print edition and all advertisements and use TheInterMountain.com as a location for special supplements and "evergreen" articles and only appeared once (and some times never) in print. 
10. Approximately what percentage of total corporate revenues is generated by:

\begin{tabular}{|l|l|l|l|l|l|l|}
\hline \multicolumn{2}{|l|}{ Subscriptions } & \multicolumn{2}{|l|}{ Advertising } & $\begin{array}{l}\text { Sales of } \\
\text { photos }\end{array}$ & $\begin{array}{l}\text { Web design } \\
\text { and/or hosting }\end{array}$ & Other \\
\hline Print & Web & Print & Web & .01 & 0 & $\begin{array}{l}\text { We do printing work for other companies } \\
\text { and individuals }\end{array}$ \\
\hline 100 & 0 & 95 & 5 & & & \\
\hline
\end{tabular}

11. Approximately what percentage of total corporate revenues would you like to generate in each of these areas?

\begin{tabular}{|l|l|l|l|l|l|l|}
\hline \multicolumn{2}{|l|}{ Subscriptions } & \multicolumn{2}{|l|}{ Advertising } & $\begin{array}{l}\text { Sales of } \\
\text { photos }\end{array}$ & $\begin{array}{l}\text { Web design } \\
\text { and/or hosting }\end{array}$ & Other \\
\hline Print & Web & Print & Web & .05 & 0 & 33 \\
\hline 50 & 50 & 70 & 30 & & & \\
\hline
\end{tabular}

12. If you can track the number of hits received by your website, can you say which areas attract the greatest attention? Please explain.

Home Page - Being the portal to our site, it draws the most attention

Local News - It is the area with current local news

Obits - As with the print edition, it attracts readership. 
13. How do members of your community access the Internet for all purposes, not just to read your publication? Are most of them active users who depend on it for a wide range of social, civic, educational and business purposes, or does the community pretty much reflect the national average in terms of age, gender, economic status, or do you think your community lags behind other communities. Please comment.

We have an older community which probably limits the overall usage. We do, however, have very active on-line group of young people and new residents. The access is quickly increasing.

14. How do subscribers access your web edition? Please enter a percentage number that you think best describes the current situation. All should total 100\%.

\begin{tabular}{|l|l|l|l|}
\hline Dial-up service & High-speed cable & DSL service & Satellite \\
\hline 10 & 35 & 20 & 35 \\
\hline
\end{tabular}

15. How important is it that your staff members learn to produce multimedia content for your publication? Please respond by placing the appropriate letter in the boxes beneath each medium.

"H" - High priority "M" - Moderately High priority "L" — Low priority

\begin{tabular}{|l|l|l|l|l|}
\hline Still photography & Audio podcasting & $\begin{array}{l}\text { Video shooting \& } \\
\text { editing }\end{array}$ & Other & Other \\
\hline $\mathrm{H}$ & $\mathrm{H}$ & $\mathrm{H}$ & & \\
\hline
\end{tabular}


16. How have the following sources of multimedia skills training served you and your staff. Please circle the number on each of the scales below that best expresses your opinion, \#1 being least helpful and \#7 being most helpful. Circle NA if this source has played no factor in your professional development.

1. West Virginia Press Association

$\begin{array}{llllllll}1 & 2 & 3 & 4 & 5 & 6 & \mathrm{x} & \mathrm{NA}\end{array}$

Least

Most

2. National Newspaper Association

\begin{tabular}{llllllll}
1 & 2 & 3 & 4 & 5 & $\mathrm{x}$ & 7 & $\mathrm{NA}$ \\
\hline
\end{tabular}

Least Most

3. Higher education, such as WVU School of Journalism

$\begin{array}{cccccccc}1 & 2 & 3 & \text { x } & 5 & 6 & 7 & \text { NA } \\ \text { Least } & & & & & & \text { Most } & \end{array}$

4. Online tutorial sites such as Lynda.com

\begin{tabular}{llllllll}
1 & 2 & 3 & $\mathrm{x}$ & 5 & 6 & 7 & $\mathrm{NA}$ \\
\hline
\end{tabular}

Least Most

5. Paid consultants

\begin{tabular}{llllllll}
1 & $\mathrm{x}$ & 3 & 4 & 5 & 6 & 7 & $\mathrm{NA}$ \\
\hline
\end{tabular}

Least Most

6. Other

$\begin{array}{llllllll}1 & 2 & 3 & 4 & 5 & 6 & 7 & \mathrm{x}\end{array}$

Least

Most 
17. Please explain how you hope to benefit from the WV Uncovered multimedia workshop initiative.

We have a young staff and older leadership. Having this hands-on opportunity gives us a chance to learn and share. We hope to close the gap between what our young reporters are doing for their personal use and what our editorial leadership is generating.

18. How important is the Internet to your staff as an editorial research tool?

$\begin{array}{lllllll}1 & 2 & 3 & \times & 5 & 6 & 7\end{array}$

Very important Not important

a. If it plays a significant role in research, please describe the types of sites educational, governmental, corporate, special interests, personal sites, etc. - - that you find most useful.

We are still deciding what we can trust. Our primary use at this time is governmental

b. If the Internet does not play a role in editorial research, what are your primary methods for researching stories?

Searching government website for data.

19. How, besides participating in the WV Uncovered project, do you intend to help your staff acquire new multimedia skills and integrate multimedia content into your publication?

We plan group reviews and sharing of the information presented at the WV Uncovered project, additional seminars and training, and new equipment purchases. 


\section{West Virginia Uncovered Participating Newspapers Questionnaire}

Newspaper Name: HtAmpshire Revicu _ Date: $3 / 9 / 09$

Your name: Charlic SEE Job title: Doblishen

1. Please enter the following information: Note $\mathrm{FTE}=$ full time equivalent, i.e. one FTE adds up to 40 hours/wk; Personal $=$ blogs on a wide variety of topics chosen at the discretion of the blogger; Topical = blog(s) devoted to specific topics such as hunting, the economy, home improvement, etc.

\begin{tabular}{|c|c|c|c|c|c|c|c|}
\hline \multirow[t]{2}{*}{ Staff positions } & \multirow[t]{2}{*}{ Total Staff } & \multirow{2}{*}{$\begin{array}{l}\text { Total 100\% } \\
\text { FTE paid } \\
\text { statf }\end{array}$} & \multirow{2}{*}{$\begin{array}{l}\text { Total unpaid } \\
\text { contributors }\end{array}$} & \multirow{2}{*}{$\begin{array}{l}\text { How many } \\
\text { produce } \\
\text { content for } \\
\text { the yeb? }\end{array}$} & \multirow{2}{*}{$\begin{array}{l}\text { How many } \\
\text { produce } \\
\text { content for } \\
\text { print? }\end{array}$} & \multicolumn{2}{|c|}{ How many blog? } \\
\hline & & & & & & Personal & Toplegl \\
\hline Reportiers & 5 & 45 & $\infty$ & 4 & 45 & & 5 \\
\hline Photographers & 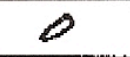 & - & - & - & سمت & - & - \\
\hline Editors & 1 & & & & & & $/$ \\
\hline $\begin{array}{l}\text { Advertising/ } \\
\text { Sales }\end{array}$ & 5 & 7.5 & $\Delta$ & $\phi$ & $\angle$ & & 4 \\
\hline Coduminists & 5 & .5 & $\Delta$ & $Z$ & $z$ & & 2 \\
\hline $\begin{array}{l}\text { Eommunity } \\
\text { eontributtors }\end{array}$ & 10 & 0 & 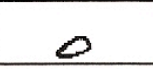 & $\sigma$ & $\Delta$ & $d$ & $r$ \\
\hline
\end{tabular}

2. What topics are covered by blogs in your online edition?

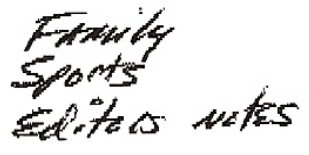

3. How do you decide what topics to blog about?

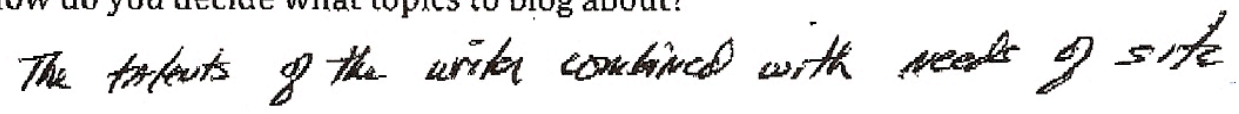

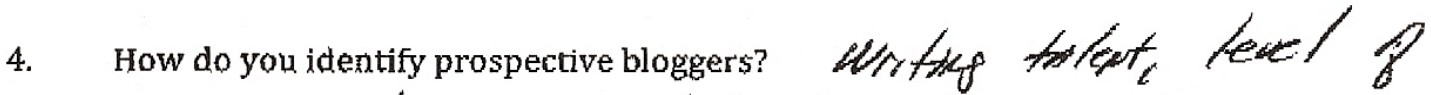
trust withyes to stele with it

Newspaper Questionnaire 1 
5. How can community members contribute to your newspaper? Check all that apply.

\begin{tabular}{|c|c|c|c|c|c|c|c|c|c|}
\hline & $\begin{array}{l}\text { Letters to } \\
\text { edithọr }\end{array}$ & $\begin{array}{l}\text { Op Ed } \\
\text { columns }\end{array}$ & $\begin{array}{l}\text { News } \\
\text { photos }\end{array}$ & $\begin{array}{l}\text { Audlo } \\
\text { clips }\end{array}$ & Videos & $\begin{array}{l}\text { Personal } \\
\text { blags }\end{array}$ & $\begin{array}{l}\text { Civic group } \\
\text { blog }\end{array}$ & $\begin{array}{l}\text { Business } \\
\text { page or } \\
\text { blog }\end{array}$ & $\begin{array}{l}\text { Govermment } \\
\text { page or blog }\end{array}$ \\
\hline Print & 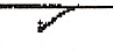 & 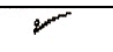 & & & 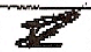 & & & 7 & \\
\hline Wab & 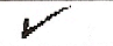 & & 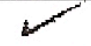 & & 5 & & 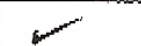 & & \\
\hline
\end{tabular}

6. Please answer the following to the best of your knowledge:

\begin{tabular}{|l|c|}
\hline How many readers subscribe to your print edltion? & $7 / 60$ \\
\hline Your online edition? & 720 \\
\hline Both? & 720 \\
\hline
\end{tabular}

7. When it comes to uploading content to your website, how much do you repurpose from the print edition?

\begin{tabular}{|l|l|l|l|l|l|l|}
\hline $\begin{array}{l}\text { Anount } \\
\text { sepurposed: }\end{array}$ & Hews & Sports & Features & Obits & $\begin{array}{l}\text { Galendar of } \\
\text { events }\end{array}$ & Other \\
\hline $100 \%$ & & & & & & \\
\hline $75 \%$ to $99 \%$ & & & & & & \\
\hline $50 \%$ to $75 \%$ & & & & & & \\
\hline Less 69at 50\% & & & & & & \\
\hline None & & & & & & \\
\hline
\end{tabular}

8. Does your web edition contain content that does not appear in your print edition?<smiles>O=[N+]1CCC2CCC1C2</smiles>

If yes, please describe this content and how it differs from print content, and explain why it appears only online.

$$
\text { breating wees striks- videss }
$$


RightFax FCC Received 03/13/2009 03:28 PM in 02:04 on line [3] for 3043683795 * $\mathrm{Pg} 4 / 7$

9. Do you use your print edition to attract readers to your website? If yes, please explain how.

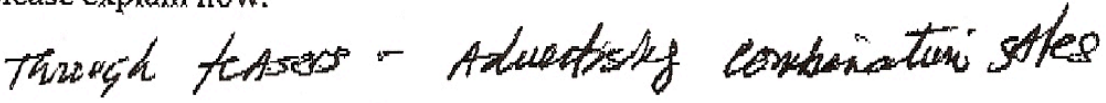

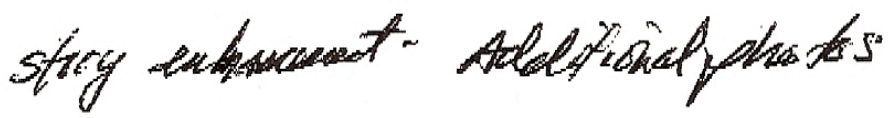

10. Approximately what percentage of total corporate revenues is generated by:

\begin{tabular}{|l|l|l|l|l|l|l|}
\hline \multicolumn{2}{|l|}{ Subscriptions } & \multicolumn{2}{|l|}{ Advertising } & $\begin{array}{l}\text { Sales of } \\
\text { photos }\end{array}$ & $\begin{array}{l}\text { Web design } \\
\text { and/or } \\
\text { hosting }\end{array}$ & Other \\
\hline Print & Web & Print & Web & \multirow{2}{*}{0} & $2 \%$ & \\
\hline 98 & 2 & 25 & 5 & 0 & $2 \%$ & \\
\hline
\end{tabular}

11. Approximately what percentage of total corporate revenues would you like to generate in each of these areas?

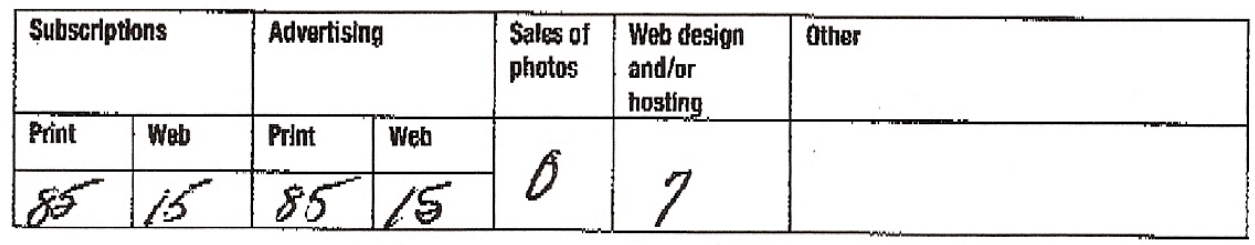

12. If you can track the number of hits received by your website, can you say which areas attract the greatest attention? Please explain.

Dbitarsies - we upload services deity

News - because of brooding sews wides

sports- general interest

47 
13. How do members of your community access the Internet for all purposes, not just to read your publication? Are most of them active users who depend on it for a wide range of social, civic, educational and business purposes, or does the community pretty much reflect the national average in terms of age, gender, economic status, or do you think your community lags behind other communities. Please comment.

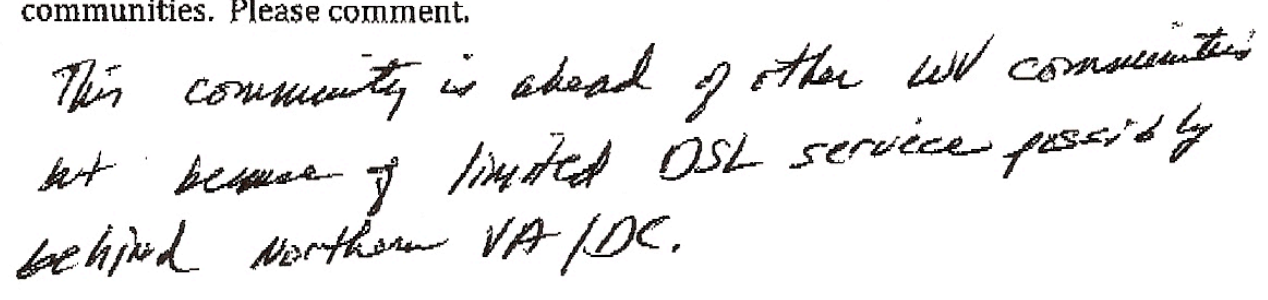

14. How do subscribers access your web edition? Please enter a percentage number that you think best describes the current situation. All should total $100 \%$.

\begin{tabular}{|l|l|l|l|}
\hline Ddal-up service & High-speed cable & DSL service & Satollite \\
\hline & & & \\
\hline
\end{tabular}

15. How important is it that your staff members learn to produce multimedia content for your publication? Please respond by placing the appropriate letter in the boxes beneath each medium.

"H" - High priority "M" - Moderately High priority "L" — Low priority

\begin{tabular}{|l|c|l|l|l|}
\hline Still photograpity & Audio podcasting & $\begin{array}{l}\text { Video shooting \& } \\
\text { editing }\end{array}$ & Othor & Other \\
\hline$f f$ & $\not f$ & $\not f$ & & \\
\hline
\end{tabular}


16. How have the following sources of multimedia skills training served you and your staff. Please circle the number on each of the scales below that best expresses your opinion, \#1 being least helpful and \#7 being most helpful. Circle NA if this source has played no factor in your professional development.

1. West Virginia Press Association

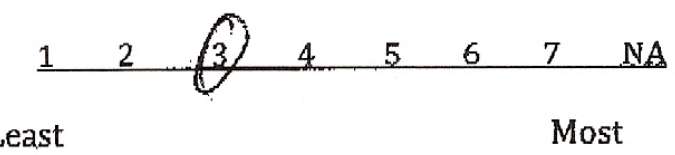

2. National Newspaper Association

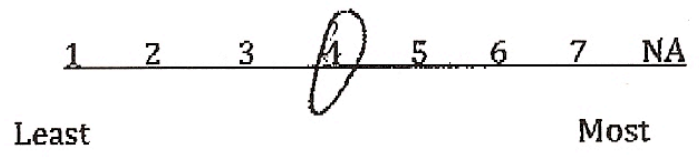

3. Higher education, such as WVU School of Journalism

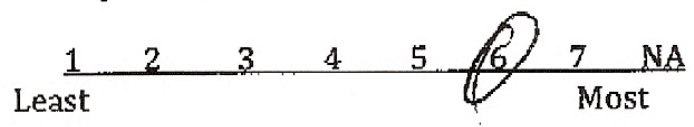

4. Online tutorial sites such as Lynda.com

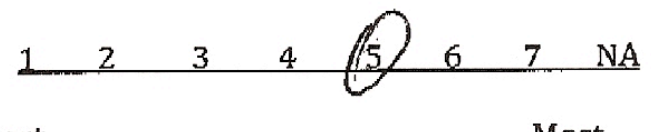

Least

Most

5. Paid consultants

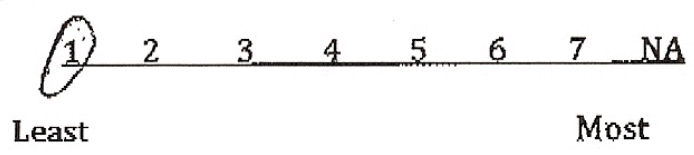

6. Other

$\begin{array}{llllllll}1 & 2 & 3 & 4 & 4 & 5 & 6 & 7 .\end{array}$

Least

Most

Newspaper Questionnaire 5 
RightFax FCC Received 03/13/2009 03:28PM in 02:04 on line [3] for $3043683795 * \mathrm{Pg} 7 / 7$

17. Please explain how you hope to benefit from the WV Uncovered multimedia

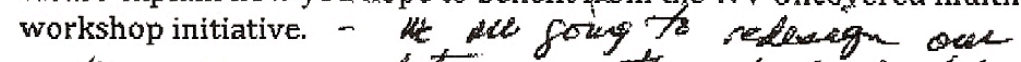

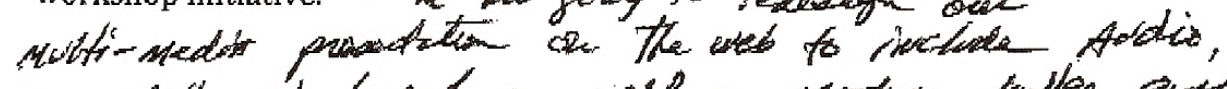

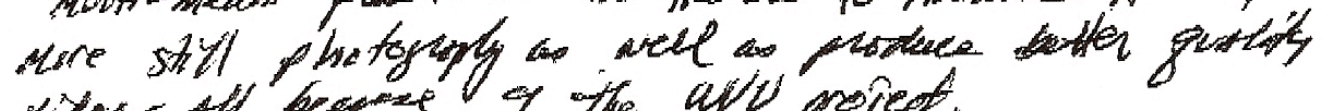
vitus - th beware of the avi propel.

18. How important is the Internet to your staff as an editorial research tool?

$$
123456 \quad 7
$$

Very important

Not important

a. If it plays a significant role in research, please describe the types of sites - educational, governmental, corporate, special interests, personal sites, etc. -that you find most useful.

other WV sites goo stogy res ad creating news

b. If the Internet does not play a role in editorial research, what are your primary methods for researching stories?

19. How, besides participating in the WV Uncovered project, do you intend to help your staff acquire new multimedia skills and integrate multimedia content into your publication?

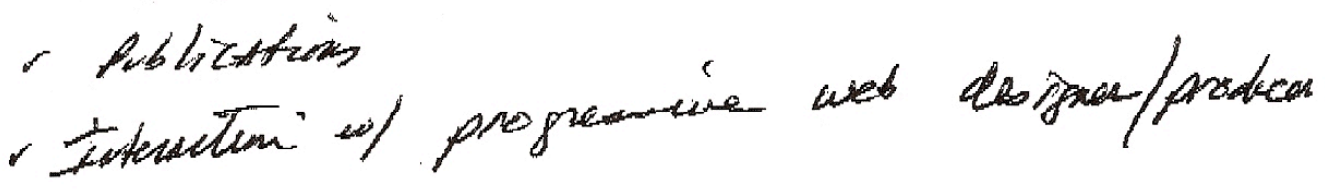

Newspaper Questionnaire 6

50 


\section{West Virginia Uncovered}

Newspaper Name: The Nicholas Chronicle

Your name: Matt Yeager
Date: $02 / 11 / 2009$

Job title: Editor

1. Please enter the following information: Note FTE = full time equivalent, i.e. one FTE adds up to 40 hours/wk; Personal = blogs on a wide variety of topics chosen at the discretion of the blogger; Topical $=$ blog(s) devoted to specific topics such as hunting, the economy, home improvement, etc.

\begin{tabular}{|c|c|c|c|c|c|c|c|}
\hline \multirow[t]{2}{*}{ Staff positions } & \multirow[t]{2}{*}{ Total Staff } & \multirow{2}{*}{$\begin{array}{l}\text { Total } 100 \% \\
\text { FTE paid } \\
\text { staff }\end{array}$} & \multirow{2}{*}{$\begin{array}{l}\text { Total unpaid } \\
\text { contributors }\end{array}$} & \multirow{2}{*}{$\begin{array}{l}\text { How many } \\
\text { produce } \\
\text { content for } \\
\text { the web? }\end{array}$} & \multirow{2}{*}{$\begin{array}{l}\text { How many } \\
\text { produce } \\
\text { content for } \\
\text { print? }\end{array}$} & \multicolumn{2}{|c|}{ How many blog? } \\
\hline & & & & & & Personal & Topical \\
\hline Reporters & 4 & 3 & 0 & 4 & 4 & 0 & 0 \\
\hline Photographers & 3 & 2 & 0 & 0 & 0 & 0 & 0 \\
\hline Editors & 4 & 0 & 0 & 4 & 4 & 0 & 0 \\
\hline $\begin{array}{l}\text { Advertising/ } \\
\text { Sales }\end{array}$ & 2 & 0 & 0 & 1 & 2 & 0 & 0 \\
\hline Columnists & 3 & 0 & 0 & 0 & 0 & 0 & 0 \\
\hline $\begin{array}{l}\text { Community } \\
\text { contributors }\end{array}$ & 6 & 0 & 0 & 0 & 0 & 0 & 0 \\
\hline
\end{tabular}

2. What topics are covered by blogs in your online edition?

At this time we do not host a blog.

3. How do you decide what topics to blog about?

$\mathrm{n} / \mathrm{a}$

4. How do you identify prospective bloggers?

$\mathrm{n} / \mathrm{a}$

5. How can community members contribute to your newspaper? Check all that apply. 


\begin{tabular}{|l|c|c|c|c|c|c|c|c|c|}
\hline & $\begin{array}{l}\text { Letters to } \\
\text { editor }\end{array}$ & $\begin{array}{l}\text { Op Ed } \\
\text { columns }\end{array}$ & $\begin{array}{l}\text { News } \\
\text { photos }\end{array}$ & $\begin{array}{l}\text { Audi } \\
\text { o } \\
\text { clips }\end{array}$ & $\begin{array}{l}\text { Video } \\
\mathrm{s}\end{array}$ & $\begin{array}{l}\text { Personal } \\
\text { blogs }\end{array}$ & $\begin{array}{l}\text { Civic } \\
\text { group blog }\end{array}$ & $\begin{array}{l}\text { Business } \\
\text { page or } \\
\text { blog }\end{array}$ & $\begin{array}{l}\text { Government } \\
\text { page or blog }\end{array}$ \\
\hline Print & 8 & 0 & 3 & 0 & 0 & 0 & 0 & 0 & 0 \\
\hline Web & 0 & 0 & 0 & 0 & 0 & 0 & 0 & 0 & 0 \\
\hline
\end{tabular}

6. Please answer the following to the best of your knowledge:

\begin{tabular}{|l|l|}
\hline How many readers subscribe to your print edition? & 3,350 (subscribers) \\
& 5,550 (single copies) \\
\hline Your online edition? & 100 \\
\hline Both? & 2 \\
\hline
\end{tabular}

7. When it comes to uploading content to your website, how much do you repurpose from the print edition?

\begin{tabular}{|l|l|l|l|l|l|l|}
\hline $\begin{array}{l}\text { Amount } \\
\text { repurposed: }\end{array}$ & News & Sports & Features & Obits & $\begin{array}{l}\text { Calendar of } \\
\text { events }\end{array}$ & Other \\
\hline $100 \%$ & & & & & & \\
\hline $75 \%$ to $99 \%$ & & & & & & \\
\hline $50 \%$ to $75 \%$ & $\mathrm{X}$ & $\mathrm{X}$ & $\mathrm{X}$ & $\mathrm{X}$ & $\mathrm{X}$ & \\
\hline Less thatn $50 \%$ & & & & & & \\
\hline None & & & & & & \\
\hline
\end{tabular}

8. Does your web edition contain content that does not appear in your print edition?

Yes No

If yes, please describe this content and how it differs from print content, and explain why it appears only online.

9. Do you use your print edition to attract readers to your website? If yes, please explain how.

Sometimes, if a story has not developed, we point readers to the web site to stay current with the latest developments. 
13. Approximately what percentage of total corporate revenues is generated by:

\begin{tabular}{|l|l|l|l|l|l|l|}
\hline \multicolumn{2}{|l|}{ Subscriptions } & \multicolumn{2}{l|}{ Advertising } & $\begin{array}{l}\text { Sales of } \\
\text { photos }\end{array}$ & $\begin{array}{l}\text { Web design } \\
\text { and/or hosting }\end{array}$ & Other \\
\hline Print & Web & Print & Web & $0 \%$ & $0 \%$ & \\
\cline { 1 - 3 } $15 \%$ & $.05 \%$ & $84.94 \%$ & $.01 \%$ & & & \\
\hline
\end{tabular}

14. Approximately what percentage of total corporate revenues would you like to generate in each of these areas?

\begin{tabular}{|l|l|l|l|l|l|l|}
\hline \multicolumn{2}{|l|}{ Subscriptions } & \multicolumn{2}{|l|}{ Advertising } & $\begin{array}{l}\text { Sales of } \\
\text { photos }\end{array}$ & $\begin{array}{l}\text { Web design } \\
\text { and/or hosting }\end{array}$ & Other \\
\hline Print & Web & Print & Web & 1 & & \\
\hline 15 & 10 & 54 & 20 & & & \\
\hline
\end{tabular}

15. If you can track the number of hits received by your website, can you say which areas attract the greatest attention? Please explain.

The index page attracts the most attention most likely because we offer such little free content on the site. 
13. How do members of your community access the Internet for all purposes, not just to read your publication? Are most of them active users who depend on it for a wide range of social, civic, educational and business purposes, or does the community pretty much reflect the national average in terms of age, gender, economic status, or do you think your community lags behind other communities. Please comment.

I believe that Internet use in Nicholas County reflects state averages fairly closely, though from anecdotal perspective, I have been surprised at the number of residents 65 and older that seem perfectly comfortable emailing and turning to the Internet when they are searching for information.

14. How do subscribers access your web edition? Please enter a percentage number that you think best describes the current situation. All should total 100\%.

\begin{tabular}{|l|l|l|l|}
\hline Dial-up service & High-speed cable & DSL service & Satellite \\
\hline 0 & 10 & 88 & 2 \\
\hline
\end{tabular}

15. How important is it that your staff members learn to produce multimedia content for your publication? Please respond by placing the appropriate letter in the boxes beneath each medium.

"H" — High priority "M" — Moderately High priority "L" — Low priority

\begin{tabular}{|l|l|l|l|l|}
\hline Still photography & Audio podcasting & $\begin{array}{l}\text { Video shooting \& } \\
\text { editing }\end{array}$ & Other & Other \\
\hline $\mathrm{H}$ & $\mathrm{M}$ & $\mathrm{H}$ & & \\
\hline
\end{tabular}


16. How have the following sources of multimedia skills training served you and your staff. Please circle the number on each of the scales below that best expresses your opinion, \#1 being least helpful and \#7 being most helpful. Circle NA if this source has played no factor in your professional development.

1. West Virginia Press Association

$\begin{array}{llllllll}1 & 2 & 3 & 4 & 5 & 6 & 7 & \text { NA }\end{array}$

Least

Most

2. National Newspaper Association

$\begin{array}{llllllll}1 & 2 & 3 & 4 & 5 & 6 & 7 & \mathrm{NA}\end{array}$

Least

Most

3. Higher education, such as WVU School of Journalism

$\begin{array}{cccccccc}1 & 2 & 3 & 4 & 5 & 6 & 7 & \text { NA } \\ \text { Least } & & & & & & \text { Most } & \end{array}$

4. Online tutorial sites such as Lynda.com

$\begin{array}{llllllll}1 & 2 & 3 & 4 & 5 & 6 & 7 & \text { NA } \\ & & & & & & & \\ \text { Mest } & & \end{array}$

5. Paid consultants

\begin{tabular}{llllllll}
1 & 2 & 3 & 4 & 5 & 6 & 7 & $\mathrm{NA}$ \\
\hline
\end{tabular}

Least Most

6. Other

\begin{tabular}{llllllll}
1 & 2 & 3 & 4 & 5 & 6 & 7 & $\mathrm{NA}$ \\
\hline
\end{tabular}

Least

Most 
17. Please explain how you hope to benefit from the WV Uncovered multimedia workshop initiative.

We hope to gain some knowledge on practical ways to effectively incorporate photos and video into our web site and begin to offer readers new content that they have not previously seen in our print editon.

18. How important is the Internet to your staff as an editorial research tool?

$$
\begin{array}{lllllll}
1 & 2 & 3 & 4 & 5 & 6 & 7
\end{array}
$$
Very important
Not important

a. If it plays a significant role in research, please describe the types of sites educational, governmental, corporate, special interests, personal sites, etc. - that you find most useful.

Government sites always play a major role in almost all stories as well as special interest sites for much of our sports reporting.

b. If the Internet does not play a role in editorial research, what are your primary methods for researching stories?

19. How, besides participating in the WV Uncovered project, do you intend to help your staff acquire new multimedia skills and integrate multimedia content into your publication?

I intend on encouraging the staff to take advantage of our subscription to Lynda.com to learn more of the software skills needed as well as possibly sending several to the Institute of Newspaper Technology at University of Tennessee in the fall. (Assuming the economy finds its way out of the crapper!) 


\section{West Virginia Uncovered Participating Newspapers Questionnaire}

Newspaper Name:

The Parsons Advocate

Date: 2-09-09

Your name: __Chris Stadelman__Job title:_Editor/Publisher

1. Please enter the following information: Note FTE = full time equivalent, i.e. one FTE adds up to 40 hours/wk; Personal = blogs on a wide variety of topics chosen at the discretion of the blogger; Topical $=$ blog(s) devoted to specific topics such as hunting, the economy, home improvement, etc.

\begin{tabular}{|l|l|l|l|l|l|l|l|l|}
\hline Staff positions & Total Staff & $\begin{array}{l}\text { Total } 100 \% \\
\text { FTE paid } \\
\text { staff }\end{array}$ & & $\begin{array}{l}\text { Total unpaid } \\
\text { contributors }\end{array}$ & & $\begin{array}{l}\text { How many } \\
\text { produce } \\
\text { content for } \\
\text { the web? }\end{array}$ & $\begin{array}{l}\text { How many } \\
\text { produce } \\
\text { content for } \\
\text { print? }\end{array}$ & \multicolumn{2}{l|}{ How many blog? } \\
\cline { 5 - 9 } & & 0.5 & 0 & 0 & 0.5 & 0 & 0 \\
\hline Reporters & 0.5 & 0.5 & 1 & 0 & 0.5 & 0 & 0 \\
\hline Photographers & 0.5 & 1 & 0 & 0 & 1 & 0 & 0 \\
\hline Editors & 1 & 1 & 0 & 0 & 1 & 0 & 0 \\
\hline $\begin{array}{l}\text { Advertising/ } \\
\text { Sales }\end{array}$ & 1 & 0 & 0 & 0 & 0 & 0 & 0 \\
\hline Columnists & 0 & 1 & 1 & 0 & 0 & 0 & 0 \\
\hline $\begin{array}{l}\text { Community } \\
\text { contributors }\end{array}$ & 0 & & & & & & \\
\hline
\end{tabular}

2. What topics are covered by blogs in your online edition?

N/A

3. How do you decide what topics to blog about?

$\mathrm{N} / \mathrm{A}$

4. How do you identify prospective bloggers?

N/A 
5. How can community members contribute to your newspaper? Check all that apply.

\begin{tabular}{|l|l|l|l|l|l|l|l|l|l|}
\hline & $\begin{array}{l}\text { Letters to } \\
\text { editor }\end{array}$ & $\begin{array}{l}\text { Op Ed } \\
\text { columns }\end{array}$ & $\begin{array}{l}\text { News } \\
\text { photos }\end{array}$ & $\begin{array}{l}\text { Audi } \\
\text { o } \\
\text { clips }\end{array}$ & $\begin{array}{l}\text { Video } \\
\mathrm{s}\end{array}$ & $\begin{array}{l}\text { Personal } \\
\text { blogs }\end{array}$ & $\begin{array}{l}\text { Civic } \\
\text { group blog }\end{array}$ & $\begin{array}{l}\text { Business } \\
\text { page or } \\
\text { blog }\end{array}$ & $\begin{array}{l}\text { Government } \\
\text { page or blog }\end{array}$ \\
\hline Print & $\mathrm{X}$ & & $\mathrm{X}$ & & & & & & \\
\hline Web & & & $\mathrm{X}$ & & & & & & \\
\hline
\end{tabular}

6. Please answer the following to the best of your knowledge:

\begin{tabular}{|l|l|}
\hline How many readers subscribe to your print edition? & 3,800 \\
\hline Your online edition? (PAID VERSION) & 30 \\
\hline Both? & 8 \\
\hline
\end{tabular}

7. When it comes to uploading content to your website, how much do you repurpose from the print edition? HONESTLY, I DON'T KNOW WHAT 'REPURPOSED' MEANS. WE USE ABOUT HALF IN SOME FORM ONLINE.

\begin{tabular}{|l|l|l|l|l|l|l|}
\hline $\begin{array}{l}\text { Amount } \\
\text { repurposed: }\end{array}$ & News & Sports & Features & Obits & $\begin{array}{l}\text { Calendar of } \\
\text { events }\end{array}$ & Other \\
\hline $100 \%$ & & & & & & \\
\hline $75 \%$ to $99 \%$ & & & & & & \\
\hline $50 \%$ to $75 \%$ & & & & & & \\
\hline Less thatn $50 \%$ & & & & & & \\
\hline None & & & & & & \\
\hline
\end{tabular}

8. Does your web edition contain content that does not appear in your print edition?

Yes No

If yes, please describe this content and how it differs from print content, and explain why it appears only online.

We do photo galleries, mostly from festivals and sporting events. We use them only online because of same considerations in print. 
9. Do you use your print edition to attract readers to your website? If yes, please explain how.

We promote additional photos and use house ads with our Web site highlighted.

10. Approximately what percentage of total corporate revenues is generated by:

\begin{tabular}{|l|l|l|l|l|l|l|}
\hline \multicolumn{2}{|l|}{ Subscriptions } & \multicolumn{2}{l|}{ Advertising } & $\begin{array}{l}\text { Sales of } \\
\text { photos }\end{array}$ & $\begin{array}{l}\text { Web design } \\
\text { and/or hosting }\end{array}$ & Other \\
\hline Print & Web & Print & Web & 0.2 & 0 & \\
\hline 29 & 1 & 69.9 & 0.1 & & & \\
\hline
\end{tabular}

11. Approximately what percentage of total corporate revenues would you like to generate in each of these areas?

\begin{tabular}{|l|l|l|l|l|l|l|}
\hline \multicolumn{2}{|l|}{ Subscriptions } & \multicolumn{2}{l|}{ Advertising } & $\begin{array}{l}\text { Sales of } \\
\text { photos }\end{array}$ & $\begin{array}{l}\text { Web design } \\
\text { and/or hosting }\end{array}$ & Other \\
\hline Print & Web & Print & Web & 1 & 0 & \\
\hline 15 & 15 & 59 & 10 & & & \\
\hline
\end{tabular}

12. If you can track the number of hits received by your website, can you say which areas attract the greatest attention? Please explain.

Obituaries (names only, not full obits) and sports photo galleries are our most popular items. 
13. How do members of your community access the Internet for all purposes, not just to read your publication? Are most of them active users who depend on it for a wide range of social, civic, educational and business purposes, or does the community pretty much reflect the national average in terms of age, gender, economic status, or do you think your community lags behind other communities. Please comment.

More than half of our younger residents (students especially) tend to have high-speed access (DSL or cable). I'd say older residents lag behind, although the library does have free high-speed terminals.

14. How do subscribers access your web edition? Please enter a percentage number that you think best describes the current situation. All should total 100\%.

\begin{tabular}{|l|l|l|l|}
\hline Dial-up service & High-speed cable & DSL service & Satellite \\
\hline & & & \\
\hline
\end{tabular}

15. How important is it that your staff members learn to produce multimedia content for your publication? Please respond by placing the appropriate letter in the boxes beneath each medium.

"H" — High priority "M" — Moderately High priority "L" — Low priority

\begin{tabular}{|l|l|l|l|l|}
\hline Still photography & Audio podcasting & $\begin{array}{l}\text { Video shooting \& } \\
\text { editing }\end{array}$ & Other & Other \\
\hline $\mathrm{M}$ & $\mathrm{M}$ & $\mathrm{H}$ & & \\
\hline
\end{tabular}


16. How have the following sources of multimedia skills training served you and your staff. Please circle the number on each of the scales below that best expresses your opinion, \#1 being least helpful and \#7 being most helpful. Circle NA if this source has played no factor in your professional development.

1. West Virginia Press Association

$\begin{array}{llllllll}1 & 2 & 3 & 4 & 5 & 6 & 7 & \text { NA }\end{array}$

Least

Most

2. National Newspaper Association

\begin{tabular}{llllllll}
1 & 2 & 3 & 4 & 5 & 6 & 7 & $\mathrm{NA}$ \\
\hline
\end{tabular}

Least Most

3. Higher education, such as WVU School of Journalism

$\begin{array}{cccccccc}1 & 2 & 3 & 4 & 5 & 6 & 7 & \text { NA } \\ \text { Least } & & & & & & \text { Most } & \end{array}$

4. Online tutorial sites such as Lynda.com

$\begin{array}{llllllll}1 & 2 & 3 & 4 & 5 & 6 & 7 & \text { NA }\end{array}$

Least Most

5. Paid consultants

\begin{tabular}{llllllll}
1 & 2 & 3 & 4 & 5 & 6 & 7 & $\mathrm{NA}$ \\
\hline
\end{tabular}

Least Most

6. Other _ Friends in industry

$\begin{array}{llllllll}1 & 2 & 3 & 4 & 5 & 6 & 7 & \mathrm{NA}\end{array}$

Least

Most 
17. Please explain how you hope to benefit from the WV Uncovered multimedia workshop initiative.

I'd like the free portion of our Web site to be an attractive one that drives traffic while allowing us to maintain a paid contention portion. I'd like it to better reflect what's happening in our community through audio and video.

18. How important is the Internet to your staff as an editorial research tool?

$\begin{array}{lllllll}1 & 2 & 3 & 4 & 5 & 6 & 7\end{array}$

Very important Not important

a. If it plays a significant role in research, please describe the types of sites educational, governmental, corporate, special interests, personal sites, etc. - that you find most useful.

Mostly government sites or other newspapers. Some interest groups or social networking sites.

b. If the Internet does not play a role in editorial research, what are your primary methods for researching stories?

19. How, besides participating in the WV Uncovered project, do you intend to help your staff acquire new multimedia skills and integrate multimedia content into your publication?

We attend seminars and have participated in online training through Kevin Slimp. Most of it likely will be trial and error. 


\section{West Virginia Uncovered Participating Newspapers Questionnaire}

Newspaper Name: The Pocahontas Tumes Date:2/24/09

Your name: Pamela Pritt_ob title: Editor

1. Please enter the following information: Note FTE $=$ full time equivalent, i.e. one FTE adds up to 40 hours/wk; Personal = blogs on a wide variety of topics chosen at the discretion of the blogger; Topical $=$ blog(s) devoted to specific topics such as hunting, the economy, home improvement, etc.

\begin{tabular}{|c|c|c|c|c|c|c|c|}
\hline \multirow[t]{2}{*}{ Staff positions } & \multirow[t]{2}{*}{ Total Staff } & \multirow{2}{*}{$\begin{array}{l}\text { Total } 100 \% \\
\text { FTE paid } \\
\text { staff }\end{array}$} & \multirow{2}{*}{$\begin{array}{l}\text { Total unpaid } \\
\text { contributors }\end{array}$} & \multirow{2}{*}{$\begin{array}{l}\text { How many } \\
\text { produce } \\
\text { content for } \\
\text { the web? }\end{array}$} & \multirow{2}{*}{$\begin{array}{l}\text { How many } \\
\text { produce } \\
\text { content for } \\
\text { print? }\end{array}$} & \multicolumn{2}{|c|}{ How many blog? } \\
\hline & & & & & & Personal & Topical \\
\hline Reporters & 3 & 2 & 1 & $a d$ & ace & 10 & \\
\hline Photographers & 3 & 2 & 1 & all & all & & \\
\hline Editors & 1 & 1 & & & & & \\
\hline $\begin{array}{l}\text { Advertising/ } \\
\text { Sales }\end{array}$ & 3 & 3 & & & & & \\
\hline Columnists & 0 & & & & & & \\
\hline $\begin{array}{l}\text { Community } \\
\text { contributors }\end{array}$ & & & & & & & \\
\hline
\end{tabular}

2. What topics are covered by blogs in your online edition?

3. How do you decide what topics to blog about?

4. How do you identify prospective bloggers? 
5. How can community members contribute to your newspaper? Check all that apply.

\begin{tabular}{|l|l|l|l|l|l|l|l|l|l|}
\hline & $\begin{array}{l}\text { Letters to } \\
\text { editor }\end{array}$ & $\begin{array}{l}\text { Op Ed } \\
\text { columns }\end{array}$ & $\begin{array}{l}\text { News } \\
\text { photos }\end{array}$ & $\begin{array}{l}\text { Audio } \\
\text { clips }\end{array}$ & Videos & $\begin{array}{l}\text { Personal } \\
\text { blogs }\end{array}$ & $\begin{array}{l}\text { Clvic group } \\
\text { blog }\end{array}$ & $\begin{array}{l}\text { Business } \\
\text { page or } \\
\text { blog }\end{array}$ & $\begin{array}{l}\text { Government } \\
\text { page or blog }\end{array}$ \\
\hline Print & $\checkmark$ & & $\checkmark$ & & & & & & \\
\hline Web & & & & & & & & & \\
\hline
\end{tabular}

6. Please answer the following to the best of your knowledge:

\begin{tabular}{|l|c|}
\hline How many readers subscribe to your print edition? & 5350 \\
\hline Your online edition? & 60 \\
\hline Both? & 3 \\
\hline
\end{tabular}

7. When it comes to uploading content to your website, how much do you repurpose from the print edition?

\begin{tabular}{|l|l|l|l|l|l|l|}
\hline $\begin{array}{l}\text { Amount } \\
\text { repurposed: }\end{array}$ & News & Sports & Features & Obits & $\begin{array}{l}\text { Calendar of } \\
\text { events }\end{array}$ & 0ther \\
\hline $100 \%$ & & & & & & \\
\hline $75 \%$ to $99 \%$ & & & & & & \\
\hline $50 \%$ to $75 \%$ & & & & & & \\
\hline Less thatn 50\% & & & & & & \\
\hline None & & & & & & \\
\hline
\end{tabular}

8. Does your web edition contain content that does not appear in your print edition?

Yes No

If yes, please describe this content and how it differs from print content, and explain why it appears only online. 
9. Do you use your print edition to attract readers to your website? If yes, please explain how.

Adventising

10. Approximately what percentage of total corporate revenues is generated by:

\begin{tabular}{|l|c|c|c|c|c|l|}
\hline \multicolumn{2}{|l|}{ Subscriptions } & \multicolumn{2}{l|}{ Advertising } & $\begin{array}{l}\text { Sales of } \\
\text { photos }\end{array}$ & $\begin{array}{l}\text { Web design } \\
\text { and/or } \\
\text { hosting }\end{array}$ & 0ther \\
\hline Print & Web & Print & Web & & & \\
\cline { 1 - 3 } 20 & 2 & 75 & 2 & 1 & 0 & \\
\hline
\end{tabular}

11. Approximately what percentage of total corporate revenues would you like to generate in each of these areas?

\begin{tabular}{|l|l|l|l|l|l|l|}
\hline \multicolumn{2}{|l|}{ Subscriptions } & \multicolumn{2}{|l|}{ Advertising } & $\begin{array}{l}\text { Sales of } \\
\text { photos }\end{array}$ & $\begin{array}{l}\text { Web design } \\
\text { and/or } \\
\text { hosting }\end{array}$ & Other \\
\hline Print & Web & Print & Web & & & \\
\hline 30 & 10 & 49 & 10 & 1 & & \\
\hline
\end{tabular}

12. If you can track the number of hits received by your website, can you say which areas attract the greatest attention? Please explain.

$$
\begin{aligned}
& \text { mews and obituanis attract the most hits. } \\
& \text { othind peoper who qive in other gloces } \\
& \text { stie cane annigh to chic. }
\end{aligned}
$$

Newspaper Questionnaire 3 
13. How do members of your community access the Internet for all purposes, not just to read your publication? Are most of them active users who depend on it for a wide range of social, civic, educational and business purposes, or does the community pretty much reflect the national average in terms of age, gender, economic status, or do you think your community lags behind other communities. Please comment.

$$
\begin{aligned}
& \text { Our Comminity has fuily arnited aceess to the Anternet. } \\
& \text { fome prople still have dialup, sthens har mo } \\
& \text { computer at aw; however, access is avilable at } \\
& \text { your libranies in the county. }
\end{aligned}
$$

14. How do subscribers access your web edition? Please enter a percentage number that you think best describes the current situation. All should total $100 \%$.

\begin{tabular}{|l|l|l|l|}
\hline Dial-up service & High-speed cable & DSL service & Satellite \\
\hline & & & \\
\hline
\end{tabular}

15. How important is it that your staff members learn to produce multimedia content for your publication? Please respond by placing the appropriate letter in the boxes beneath each medium.

"H" - High priority "M" — Moderately High priority "L" — Low priority

\begin{tabular}{|c|c|c|l|l|}
\hline Still photography & Audio podcasting & $\begin{array}{l}\text { Video shooting \& } \\
\text { editing }\end{array}$ & Other & 0ther \\
\hline$H$ & $M$ & $L$ & & \\
\hline \multicolumn{4}{|c|}{$($ fon mur) }
\end{tabular}

Newspaper Questionnaire 4 
16. How have the following sources of multimedia skills training served you and your staff. Please circle the number on each of the scales below that best expresses your opinion, \#1 being least helpful and \#7 being most helpful. Circle NA if this source has played no factor in your professional development.

1. West Virginia Press Association

$\begin{array}{lllllll}1 & 2 & 3 & 4 & 5 & 6 & 7 \\ & & & & & & \text { Most }\end{array}$

2. National Newspaper Association

$\begin{array}{llllllll}1 & 2 & 3 & 4 & 5 & 6 & 7 & \mathrm{NA} \\ & & & & & & & \\ \text { Most }\end{array}$

3. Higher education, such as WVU School of Journalism

$\begin{array}{lllllll}1 & 2 & 3 & 4 & 5 & 6 & 7 \text { NA }\end{array}$

4. Online tutorial sites such as Lynda.com

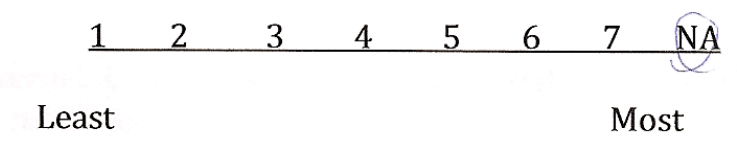

5. Paid consultants

$\begin{array}{llllllll}1 & 2 & 3 & 4 & 5 & 6 & 7 & \text { NA }\end{array}$

Least Most

6. Other

\begin{tabular}{llllllll}
1 & 2 & 3 & 4 & 5 & 6 & 7 & $\mathrm{NA}$ \\
\hline
\end{tabular}

Least

Most

Newspaper Questionnaire 5 
17. Please explain how you hope to benefit from the WV Uncovered multimedia workshop initiative.

$$
\begin{aligned}
& \text { The Grahntas times' claim to fame has tren its } \\
& \text { abritity to stay in the past. Sid like to change } \\
& \text { that luy useng this projict to heep pnopee us } \\
& \text { to the head of the hend yon a charge. }
\end{aligned}
$$

18. How important is the Internet to your staff as an editorial research tool?

$$
\begin{array}{lllllll}
1 & 2 & 3 & 4 & 5 & 6 & 7 \\
\hline
\end{array}
$$

$$
\text { Very important Not important }
$$

a. If it plays a significant role in research, please describe the types of sites - educational, governmental, corporate, special interests, personal sites, etc.- that you find most useful.

$$
\begin{aligned}
& \text { Wvigov } \\
& \text { wriacom } \\
& \text { educational websites }
\end{aligned}
$$

b. If the Internet does not play a role in editorial research, what are your primary methods for researching stories?

19. How, besides participating in the WV Uncovered project, do you intend to help your staff acquire new multimedia skills and integrate multimedia content into your publication?

$$
\begin{aligned}
& \text { Panticiputio in this Groject is oun genst } \\
& \text { stip. I hope it wic giv us the tors } \\
& \text { we nue to Continu education, likely } \\
& \text { thaingh grvfa }
\end{aligned}
$$

Newspaper Questionnaire 6 


\section{Appendix 3.}

\section{Video Training Session- exit interviews}

1. From the West Virginia Uncovered Training Project, what are some of your favorite tips or tricks you've learned?

2. Since the workshops began in February, has your newspaper started to incorporate more multimedia into their Web site? This could include anything from picture slideshows, to video or audio or anything that you have learned from the training sessions thus far.

a. If yes, tell me about some of the multimedia elements added to your site.

b. If yes, how has the community/your readers responded?

3. What are some of the ways you would like to see more multimedia added to your site?

4. Are you working on any stories that will have multimedia elements on your site?

a. If yes, tell me a little about the assignment.

5. Are you currently working on any projects or story assignments that you think could benefit from adding multimedia elements? Tell me about those stories ideas.

6. Can you tell me about the motivation of your newspapers staff to increase the amount of multimedia on your site?

7. If you were offered the opportunity to participate in more training sessions, even those outside the West Virginia Uncovered Project (at little or no cost), would you accept?

a. Why or why not?

8. What are some of the additional topics you would like to see covered in future training sessions?

9. If you were given the opportunity to learn multimedia using an online site, would you participate?

a. Why or why not? 
b. If yes, what are some of the topics you would like explore in an online training site?

10. How do you feel the WV Uncovered training sessions have benefited your newspaper?

11. Do you have any additional thoughts or comments about the training sessions? 


\section{Appendix 4.}

\section{WV Uncovered Training Sessions Transcribed Exit Interviews}

\section{Charlie See, The Hampshire Review}

CSee: My name is Charlie See and I'm the publisher of the Hampshire Review in Romney, West Virginia.

JMR: Just a start of question, what has been one of your favorite tips or trick that you've learned?

CSee: Uh, the video today was really, was really neat. Bill had some good things about the audio, but uh, the video, the first ten seconds, and how to capture the audience.

JMR: Since the workshops began in February, we know that your site has a little bit of multimedia on it, have you added more since the project started.

CSee: Well, we're getting ready to. In fact, on Monday, we're going to put up a media bar which Bill had initially talked to us about, and uh, and we're going to have audio on it, and a place for slideshows and our video and... We actually sold our first commercial too. Video commercial. So we're pretty excited about that.

JMR: Are there any stories that your staff is currently working on that could benefit from multimedia or that you trying to work in that could have a multimedia element and could you tell me a little bit about that?

CSee: Yeah, the Great Depression. We're uh, we're going to do several things on it. We're actually going to copy a lot from what West Virginia Uncovered is doing. Uh, we really like the graphics that you all did, we think it's really fantastic. In fact, Sallie was just talking to Bill about graphics and what programs you were using and everything like that.

JMR: And how has your staff been motivated to umm, start working on these different projects and add a little bit more elements to them.

CSee:: Well.. it's tough to get staff motivated, it really is. Because they see it as a little bit more work. So uh. We try to bring as many people to these classes as we could in order to get them motivated. And today they seem to be a little bit more excited about it, and everything. We're really trying to get our reporters to where they'll take a Flip video with them whenever they go out and they'll use it and they just see that as one more thing they have to do besides taking notes and using a recorder and taking pictures. So it's.. it's a work in progress. 
JMR: And umm... Can you, tell me a little bit about if you were offered the opportunity to more session either with the West Virginia Uncovered Project or outside, would you take that opportunity and why or why not?

CSee:: Yeah, we definitely would. It's, it's uh, hard to get training in this. It really is. It's uh, that one-on-one contact is much better than on the web where you watch a, you know, a video or something like that. So uh, we definitely would keep participating.

JMR: So you like the more uh hands-on, interactive in a classroom setting rather than an online training site?

CSee: Absolutely. Absolutely. It's uh, just more personal and uh, and you're able to get meaning, more meaning out of it.

JMR: Outside of the topics that we've covered, are there anything that you can think of off the top of your head that you would like to explore, any graphics or anything like that?

CSee: Probably the biggest stumbling block we have and probably any newspaper's having is, hey, somehow we have to get the funding for this. I'd love to me, for someone to tell me how I can pay for all of this. And we're not paying for ours now. I mean, it's definitely not, uh paying the way. But we believe in it enough that we're going to keep doing it. But, I think at some point in time, for all newspapers to buy into this, funding is going to have to come to the top and say okay here's how you do it.

JMR: So you would like to see a training session maybe in like advertising, or umm, how do you build more revenue?

CSee: Absolutely. And advertising will be part of it there's no doubt about it. Uh, there's some sites that's doing some work with credits. And we're, we're looking at some of that and we think that our next site will sell individual stories. And we have a site now that you can, you can, get a subscription, but uh, not everybody wants to a subscription to a newspaper, they might just want to buy a couple different things. One thing, we've done too is, we've not given away our content. And we didn't buy into that back when everybody said give your content away. In fact we were being criticized for not giving our content away. And now it's starting to swing back the other way. And we think we're in a position to make a little bit of money that way.

JMR: And how do you think overall that your newspaper has benefited from these training sessions?

CSee: Uh, overall great. I mean it's great, It's nice to work with students. I'm a former teacher. So uh, I really enjoy getting around young people and uh, and getting their ideas and see where they're going, where you all are going. Your future's completely different than what ten years ago it was. You know, they were training to being trained to write for newspapers and now it's a completely different atmosphere. 
EM: Alright, first of all... how did you get involved with the project?

CSee: That's a very good question. Uh, Bill and I've kept in touch over the years and I assume, you know, thinking back, John came to our place one time and did a story about the, about the review. When he was working in Pittsburgh as a freelancer. And then I think it came about that he e-mailed me and then Bill got involved and we'd worked with Bill before. So that's kinda how it came around.

EM: So when you first signed up for it, what we you looking forward to most about the project?

CSee: You know, I really didn't know. I really didn't know what was going to happen. But uh, we're always ready for new and different things. New mountains to climb.

EM: What's been your favorite part about being part of it? Because you were one of the later newspapers to join actually, so...

CSee: Uh. There again, working with the students. Seeing, seeing the student's work. And uh, and just the learning process.

EM: And do you have anything you would like to see change maybe. Someone else mentioned that maybe designate student's to work in one county so that they're working with the editor's more and it's not just parachute journalism where, you know... Would you agree with that? Or do you like meeting the different student's, would you like to have more one-on-one interaction. Or something else that could be changed? Maybe the stories that we're doing, maybe like different types of stories?

CSee: No, I think the stories are right on target. I really do. And I think the way the student's come in and did the stories, I think are very helpful to them. And it was helpful to us. Uh, as far as things to change, I think probably, we would've been better off to join the whole group, rather than have sessions on our own. Because that group interaction, talking with others, I think probably wou; d've benefited us. And that was my decision. That I, uh, didn't want to bring my staff all the way to Elkins every time. But now, I think probably it would've been better.

EM: One more question. Do you plan to stay with the project and why or why not?

CSee: Sure. Sure, I think uh, it's a great, it's a great project, uh. At some point in time, I'd even like to, and this is an idea that Bill threw out, I'd like to have an intern from WVU who's multimedia trained in the summertime. We're not to do an intern this summer for the first time in 15 years, but maybe next summer I'd like to bring somebody in that has some training and actually work with us. 


\section{Chris Stadelman, The Parson's Advocate}

JMR: Just an opening introduction question, from the Uncovered Training project, what are some of your favorite tips or tricks that you've learned so far?

CS: All of it's been great. I think, umm, it's been really practical experience. Being able to actually go out and get some audio. Umm, we're already thinking about ways we can use it on a weekly basis. So you know, I think it's just been incredibly hands on, which is really helpful.

JMR: Ok, I forgot to do this at the beginning but go ahead and state your name and you position, title.

CS: My name is Chris Stadelman and I'm the editor of the Parson's Advocate, a weekly newspaper in Tucker County.

JMR: Ok so the workshops began in February, umm since then, have you started to incorporate any kind of multimedia into your Web site?

CS: We've started looking at how to do that. Right now, it's just been the West Virginia Uncovered projects that we're linking to. Uh, but we've started playing around with it and at least thinking about how to do it. Umm, it's a matter of trying to get all the technology ready and get the hardware ready first.

JMR: And how are your readers responded to the multimedia on your Web site. Have you had any feedback or can you tell me a little bit about that?

CS: We've done more photo galleries, which is sort of, going back to the very first seminar. So we've been able to that and we've had great feedback. It's one of our most popular sections on the Web site. So that's been a big plus. Umm, and the few videos we have, we've gotten really good reactions, especially from the folks that have been in them. I think you know, we're still working on how to market them a little better.

JMR: Ok, and what are some of the way, or some of the ideas your thinking about adding more multimedia into your site?

CS: Well, we live in a county that's umm... got a great arts community. Uh, it's got a lot of outdoor activities, so I think we'll really be able to find some of those neat umm stories where we can go out hiking, go out to the beautiful areas in Tucker County. I think there will be some great video, landscape type video that we can really do. Umm, as well as some of the music and the live, you know, live bars and restaurants that do that on the weekends.

JMR: I know your staff is small, but can you tell me about the motivation of your staff to incorporate multimedia.

CS: (Laughs) Kelly and I are very excited about it, that would be the umm, but, but I think it's also our, umm, helping energize our advertising folks too. She's working on selling more 
Internet ads. I think the whole concept has gotten everyone to focus more on our Web site in the community. Which you know, makes it a little easier to sell some of the ads for the Web site too.

JMR: Have you thought about adding some community support? Uh, some contributing photos or anything like that.

CS: We've started to figure out who we might want to do that with. There are several, umm, people in our community, that are doing blogs and that sort of thing. So we might try to connect with them. Link their blog with our. Figure out how we might be able to work together or some of those things.

JMR: Just a couple closing questions for me and then Elaine will ask you some questions. Umm... Can you tell me if you had the opportunity to do more training sessions at either little or no expenses outside the West Virginia Uncovered Project would you except and why or why not?

CS: If they're as good as these seminars, absolutely. We've already talked about trying to have a lot of the West Virginia Uncovered Project's stuff recovered at the West Virginia Press Association annual convention. It's been invaluable because it's so practical and hands-on. I've done training seminars at Poytner and API. Umm, and these have been better than those frankly.

JMR: Um, if you were to continue in those training sessions, what are some of the topics, other than the ones we've covered here that you would like to see.

CS: The multimedia has been great. I don't think it would hurt to go back and do even some basic reporting and writing. You know I think those kind of seminars are always helpful. One thing that has really struck me is how important it is to be a good reporter before you can make any use of any of the multimedia. Whether its audio, video, all of it comes back to being a good reporter, asking good questions and getting information and then its just a different format to use it in.

JMR: Ok. And then uh, if you were given the opportunity to learn multimedia on and online Web site, would you take that opportunity as well?

CS: I would certainly look at it. I think being able to be in the same room, interacting with not only the people who are leading the instruction, but the others who are learning is, is probably more valuable. Umm, it would be less time consuming. I guess you wouldn't have the travel. Umm, but I really like the idea of everybody being in the same room together.

JMR: How do you feel the West Virginia Uncovered Training sessions have benefited your newspaper?

CS: I think it's going to really help us create a buzz. Umm, there's not a lot of online presence in our small community, which I think is true for a lot of West Virginia and certainly the smaller areas of West Virginia. So, I think if we can show that this sort of multimedia, online, exciting opportunities are there, umm, people will really buy into it. And it will help us a lot with younger 
readers too. Yeah, we know kids want use iPhones and iPod Touches and all that kinda stuff so it's really going to help us connect with them.

EM: So mine's more focused on behind the scenes, how your number one went for West Virginia Uncovered. So if you could talk about how you got involved with West Virginia Uncovered, what your expectations were, where you are now.

CS: Umm, well, the way I got hook up, I think is I've known John Temple for years when I was at the Daily Mail. He and I worked together on the bureau class, which I guess was sort of I guess... I guess a precursor to this to this to some extent, where we were just having print stories written by WVU students. Umm, it was a great resource for us then, umm, to get good content from a different area. And I think it provides an opportunity for students to get real hands on experience, you know, working with a front line editor. So when John asked me if I would participate in another project, it was a no-brainer for us.

EM: Umm, so what were you told was... What was your involvement supposed to be and what has it been and have your expectations been fulfilled or...

CS: Umm, I think you know we, sorta started out with some brainstorming for stories that might be available to do in Tucker County. Umm and how we might approach some of those. Umm, and that's been, and I think that's been a feeling out process. Umm, it's almost, I think, Andy and the folks in Morgantown have acted more as the City Editor type working one-to-one. To be honest, I probably like a little more interaction with the students working on the pieces for us. I think that would help. Umm, at time it can be parachute journalism, which I think is difficult to practice whether your at the New York Times or at a weekly in Tucker County. To have the background of everything that's going on in the country, the personalities that are involved, you know, the history of the stories. I think the more interaction the student's have with the actual editors actually in the community, the better.

EM: Ok, and... umm, what would you like to see change maybe next year? Would it be more student's being involved or more student's actually coming to the office and talking to you more or is it different types of stories that we're not covering?

CS: I think the different kinds of stories have worked out pretty well. In a perfect world, I think it would be great to have a couple of students, whatever works out, you know, two, three, sort of assigned to each county. Umm, its been neat to work with different students, but I think if we were able to build a relationship over a couple of semesters, ideally a couple of years, where they could get to know Tucker County. They could get to know, you know, our newspaper, how we do things, umm... I think that would be a big benefit to us and it might help them do the second and third layers of the stories, because I do think its hard to drop into Tucker County one day, Pocahontas County the next. Kanawha County another day. Umm, so if we could build those relationships, umm, I think that's really important, especially for rural journalism to develop that over time. 
EM: Any other comments about the project in general?

CS: Yeah, I think its, everything's been fantastic. Bill Kuykendall's been a great addition. The student's you know, Andy and John have been great to work with and we're really happy to be a part of it. 


\section{Pam Pritt, The Pocahontas Times}

JMR: You can go ahead and say your name for me and your title and your newspaper

PP: My name is Pam Pritt. I'm the editor and publisher of the Pocahontas Times in Marlinton.

JMR: Just a quicker opener, from the West Virginia Uncovered Project, what are some of your favorite tips or tricks that you've learned so far?

PP: I really liked the tips about how to upgrade our Web site, and how to do better with that. The Pocahontas Times has for so long been behind the curve in development of its print product. And we're finally getting places with it, but to be able to be ahead of the game with our Web site, I think is a fantastic thing that WVU has given to us.

JMR: Since the workshops began in February, is there any type of multimedia that you've added to your Web site? Or any kind of planning stages to add more?

PP: We haven't added anything yet, but we have plans. We've sat down and talked. We wanted to wait until the end of these sessions, Until we decided which equipment we wanted to purchase. Until we decided which stories would really be a good fit and so we have a running list of ideas of both stories and the equipment that would go along with them. We just want to see what our most important thing will be.

JMR: And what are some of the ways you would like to see more multimedia? It is, uh, picture slideshows, videos, podcasts?

PP: We're going to begin with slideshows. We're going to, uh, we're going to, but very quickly I want to go into video. Podcasts will come quite a bit later for us, I think.

JMR: And how's your staff feeling about motivated about multimedia? Is there an excitement or could you tell me a little bit about some of their feelings about adding multimedia elements to the Web site.

PP: The staff, umm... Jeff Hamil has already, uh, begun. He's already bought, got his own video camera and he has practiced and has something up on a site that no one can see but us. And so, that's been great. Suzanne Stewart has been thinking more about her photography shots and she was already a very good award-winning photographer to begin with, but she has been thinking more about how to incorporate more of those for her web stories. Uh, it's been very motivational for us.

JMR: And you don't currently have any outside contributors, outside the newspaper?

PP: We have a couple of stringers who do some town councils. But nothing, nobody whose contributing anything for our web. 
JMR: Have you thought about adding any community, maybe blogs or slideshows or accepting community photos?

PP: I've given it some thought. I'm umm, having read blogs, uh on major national news sites, I'm a little bit weary of that. And how personal people get in their anonymity. To other people and when you live in a small community and people know each other, you're always going to be wondering who that person was. We just haven't gone there yet.

JMR: And umm, are you currently working on any projects or stories that you think could benefit from multimedia?

PP: Absolutely. Umm, we have an ongoing story, well quilters are big in our county, so we want to talk about those because that's very visual. We have so many musicians. We want to do more with those people on our Web site. We have a lot of things that we'll be able to... We're calling it our heritage project actually. Our musical heritage, our quilting heritage, you know, our outdoor heritage. That's our broad topic.

JMR: And umm, if you were offered the opportunity to, if you were given the chance to participate in more training sessions even outside the West Virginia Uncovered Project, do you think you would participate? You can tell me why or why not, if its time constraint or...

PP: I want to participate. Time is a factor. I mean, today I had a conflict because I covered a trial last year and the sentencing was today so I had to send somebody who had never been to court just to take notes for me and get the information. So that was, this was, this was, a tough one for me today. This is important because this about the future... maybe not of our print product, but of our business. And so, I need to be, I need to be here. And so I'm absolutely about training and more education for both myself and our staff.

JMR: Do you think it would maybe be more feasible for someone, to or anyone in your staff, yourself to do online training instead? Maybe that would, if you were given that opportunity would you do that instead or...

PP: I would give online training a try. But I'm kind of old school. So I like this, I like the ability to be here, take notes, ask questions. It's, it's better for me. But I would be willing to give webinar a try.

JMR: And what are some of the additional things if you were to participate in another training session, what are some of the additional topics you would like to see outside of what we've done so far.

PP: Well, off the top of my head, I really can't think of any. But, I'm sure there are some out there.

JMR: Ok. And umm... so how do you think these training sessions have benefited your Web site? 
PP: Just in the fact that we can develop it. We have a better feel for how to develop it.

EM: Alright so, year one is over, and we started out with four, five, six students now and added four more so what's been your experience, umm... well first of all tell me how you got involved with the project?

PP: I guess it goes back a few years. John Temple actually came and to Pocahontas County to interview me and my partners about the Pocahontas Times for American Journalism Review and that's before he became a professor, at WVU. So that's how he knew about us. When his student came up with the idea for West Virginia Uncovered, he contacted me.

EM: So what were your expectations going into the project?

PP: I didn't really have any from the intial call except that student's would be writing stories and it would be in print and online. And, you know, that we would get some benefit from, from your content and you would maybe get some benefit from already being published. And you would have that experience to go on. But other than that, I really just... I learned as a reporter not to have expectations beforehand.

EM: Umm, so... looking back on it, what would you, what would I guess, we're you pleased with being part of it? Do you want to continue being part of it and why?

PP: I am pleased to be part of it. And umm, and I would like to continue to be part of it. And I think the importance of it has umm... It's been a really good two-way relationship. We have learned so much and gained so much from our workshops, but I hope that the students have learned that community journalism's very important. And that there's personal stories that the students have done about our, uh, dog catcher, and our women's prison where the birthing center is. I hope that those things have made what journalism really is personal to the students.

EM: Do you wish there was more interaction with you and the students? Do you feel a disconnect because we're traveling around county to county? We're not staying in one county just continuously doing stories.

PP: A little bit. Umm... but not enough to really, I don't think it deters from the project or from our end.

EM: Could you say that again, but say, like repeat my question. Like "I think there might be a little bit of a disconnect..."

PP: Sure. I think there might be a little bit of a disconnect, but not enough that it deters from the project itself. But umm, the last story we got was late for our deadline and it was supposed to be page one color, but it ended up being page six, still in color, because we had to have our pages set. 


\section{Matt Yeager, The Nicholas Chronicle}

EM: Introduce yourself and your title

MY: My name is Matt Yeager and I'm the editor for the Nicholas Chronicle in Summersville, West Virginia.

EM: From the West Virginia Uncovered Project, what are some of your favorite tips or tricks that you have learned.

MY: Well, umm, the workshop that was done, when he talked about, when Bill Kuykendall talked about lighting for portraits and umm. (under breathe, what else did he talk about). I guess you can edit out the pauses?

EM: Yeah.

MY: Umm. Lighting, portraits and what else? Umm, the landscapes. That was real helpful. And the parts they did about maps and graphics was helpful also. There was something else from that workshop too. Is it on that sheet?

EM: Since the workshops began in February, has your newspaper started to incorporate more multimedia into their Web site? And if so, how and what?

MY: Umm, we've only done one thing since we started out. And it's not a, its just a matter of time pretty much with having a larger paper and a limited staff and putting a lot of those resources to the print product every week. Umm, we've done one thing on the Web site about a umm fly fisherman who ties flies in umm Craigsville, West Virginia. And umm, but we would like to expand it a lot more. You know a lot of ideas especially from you know, the audio and the video and the photography segments about, umm, ways that we can incorporate... There's a lot of story ideas that fit a lot more naturally into this medium, into multimedia, than they would on the printed page. And there's a lot more, there's a lot more appeal to umm, people who wouldn't normally have much of an interest in, you know, looking at the printed paper.

EM: That was actually a question that I was going to ask you. Are there any stories specifically that you can think of that could really be enhanced with multimedia or that your staff has already done and that you could, you know, go back and do follow-ups on with multimedia or something?

MY: Umm, one thing that I was thinking about today, I mean, I've thought several stories ideas that have come to me over the course of the workshops. One thing, one thing, that I was thinking about today though was umm, there was a town called Gadd and it was where umm when the umm river was dammed, the Gaulley River was dammed to make Summersville Lake it kinda covered where Gadd used to be as a farming community there. And umm, it would be interesting while those people are still alive who lived in the farming community, umm and they're getting fewer and far between, umm to take them out to some of these sites and when the waters recede in the winter and so you could take., umm, there's a lot of places that are accessible to take these 
people and umm, you could have them tell their stories on video or audio or both. And umm, to point out these landmarks with, where things used to be. You can actually see when you go down to the lake now, without the water being there, umm, you can see where umm, there used to be bridges and with the lake going down, it falling back into its natural creeks, the creeks just fall right back underneath the bridges again. Like they used to be. And umm, you see a lot of umm, farmhouses and things like that, that used to be there. Umm just the frames and you know, the foundations. But umm, I think that would make one interesting thing. Especially before those people pass on. And they'll... one thing that was funny, a story about that was that when they first, umm, made Summersville Lake and they made the umm, dam there, they were looking for a way to umm recognize the umm Gadd community and what they had given to the lake and everything and umm, at first they wanted to call the dam, Gadd dam. But they umm, you know, thought better of it and called it Summersville dam.

EM: That's cool. I never knew about that. That would be really interesting. Especially to catch those people.

MY: Well there's just a lot of, you know, the stories that you all did for the Web site, umm they just, they bring up a lot of other story ideas that we'd never thought of before. Umm, and it's just been real helpful to get a different kind of mindset there. And you know, you, in the community every day, you kinda come set looking at things in particular way and then when you get people like you all that aren't from the area, looking at them in a different way, umm you give us all kinds of ideas. You know, different ways to approach the same topics that we wouldn't have thought of otherwise.

EM: Cool. Umm... let's see... can you tell me about the motivation of your news staff to increase the amount of multimedia on your Web site.

MY: Umm, I think that, the people that have attended with me have offered several ideas of other stories that we could pursue. Umm... there was a real famous uh, or locally famous man named Edwin Pratt and umm, one of the staff members that has attended with me was talking today about umm, the photo essay type thing that you all were having out there. Umm where you know, there's probably hundreds of people you could find in the communities to speak at length on Edwin Pratt. And how you could, you know, umm, put that on the Web site with video. I mean with photos and audio of people that knew the man real well. He's umm, you know, people you him all over, especially people that used to live in the community and moved away. And it would be real popular with them.

EM: That's cool. Umm, what are some additional topics you would like to see covered in the future training sessions? Beyond video today, audio and other day and photography. Would it be basic reporting and writing techniques?

MY: That would help a lot. I mean to be honest with you. Because I think that, in the case of I think most community papers in the state, they don't have journalists educated. I mean journalists, people who have actually going to journalism school working for them. They have people probably from the most part that have gotten bachelor's degrees in you know, history or umm, English, or other areas, but they don't have a solid foundation in umm, just basic writing, 
you know. Journalism writing, and just, you know, the questions that need to be answered. Umm, you know, a good way to write a lede, and I think that that would help a lot. But you know, then again, its I'm sure that you all have covered the high points as far as you know, the multimedia and umm, and given us a lot to work with as far as actually getting us rolling and everything. Umm... and giving us enough that we can start producing stories on our Web sites.

EM: Ok. If you were given the opportunity to learn more multimedia using an online site instead of actually coming here, do you think you would use it, umm why or why not and would it be beneficial or do you like the one-on-one interaction?

MY: Umm... I don't think I would use it if I went to Lynda.com or something like that. Even if they do have, some, I'm sure that they do have some individual videos that are basically on the same types of things. But I don't think that I would umm, approach, I don't think that I would incorporate it into the Web site like I would with having you all an Mr. Kuykendall here. And, umm... you know there's a lot of... he's... Mr. Kuykendall been, he's a great motivator of you know, looking at these people in your community closer and actually umm, giving them a voice to umm... speak you know and just umm, exploiting that. Not exploiting it, but just using to benefit your Web site as much as you can.

EM: Umm... One last question. How do you feel that the West Virginia Uncovered Training Sessions, for the most part, have benefited your newspaper, your newspaper staff, your Web site?

MY: I think they benefit, like I say, we're going to pursue a lot more story ideas with it. I think that it, its umm... I think that most community papers have been scared to a certain degree of using the Internet because they're afraid that they're going to take umm, people away from their print product. But I think in using these multimedia techniques you all have taught over the three sessions umm I think that you know, we can. We tell the stories a lot different I think than anybody else does. And we can use our sites to expand on the audience a lot more than what we have with just simply the print product. And at the same time since its going to, it's different types of content we're not going to draw people away that would be buying the print product traditionally. We're just going to umm be exposing a lot more people to the community that wouldn't otherwise have any kind of exposure.

EM: Cool. Okay so how did you get involved with West Virginia Uncovered?

MY: Umm... I believe umm, John Temple contacted me to ask me if I would be interested in running some, umm, pieces that the project had produced on Nicholas County subjects. I had heard through Chris Stadelman and then Pam Pritt that is was a good project and that you all had already produced a least a story or two for each one of those papers. And they were real pleased with the results from it. So it was pretty much a non-decision really at that point.

EM: Cool. And, what would you like to see changing, this is the first year for it and we're changing things and adding more students, umm when it comes to the students reporting stories. Do you like the stories we've done, do you wish they would cover different issues or work with you one-on-one with editing, or finding sources? Is there anything like that that you think needs to be changed? Or do you think the way we're doing it works? 
MY: Yeah, I think it works perfect. I mean not to be a Pollyanna or anything. I couldn't be happier with the stories that were turned in. And I think, that, I'm sure that we got a lot of people to look at your all's site. At the movies, and then look at your all's site even further for umm, other things. But I couldn't be happier with just the way that it worked. I don't know that it seems like it might be kinda cumbersome for umm, a student to be a fulltime student and try to work with a weekly paper halfway across the state. And umm, it seems like it works a lot better the way that we did it this past year.

EM: Okay, and you plan on staying with the project and if so, why or why not.

MY: Oh yeah. Yeah, plan on anything that the project does I would like to continue my participation in it. Umm, I think that, you know, my staff members and I, umm, learned a lot from the project and umm, I'd like to continue with it. 


\section{Appendix 5.}

\section{Examples of Final Cut Video Timeline}

"Shooting Basics"

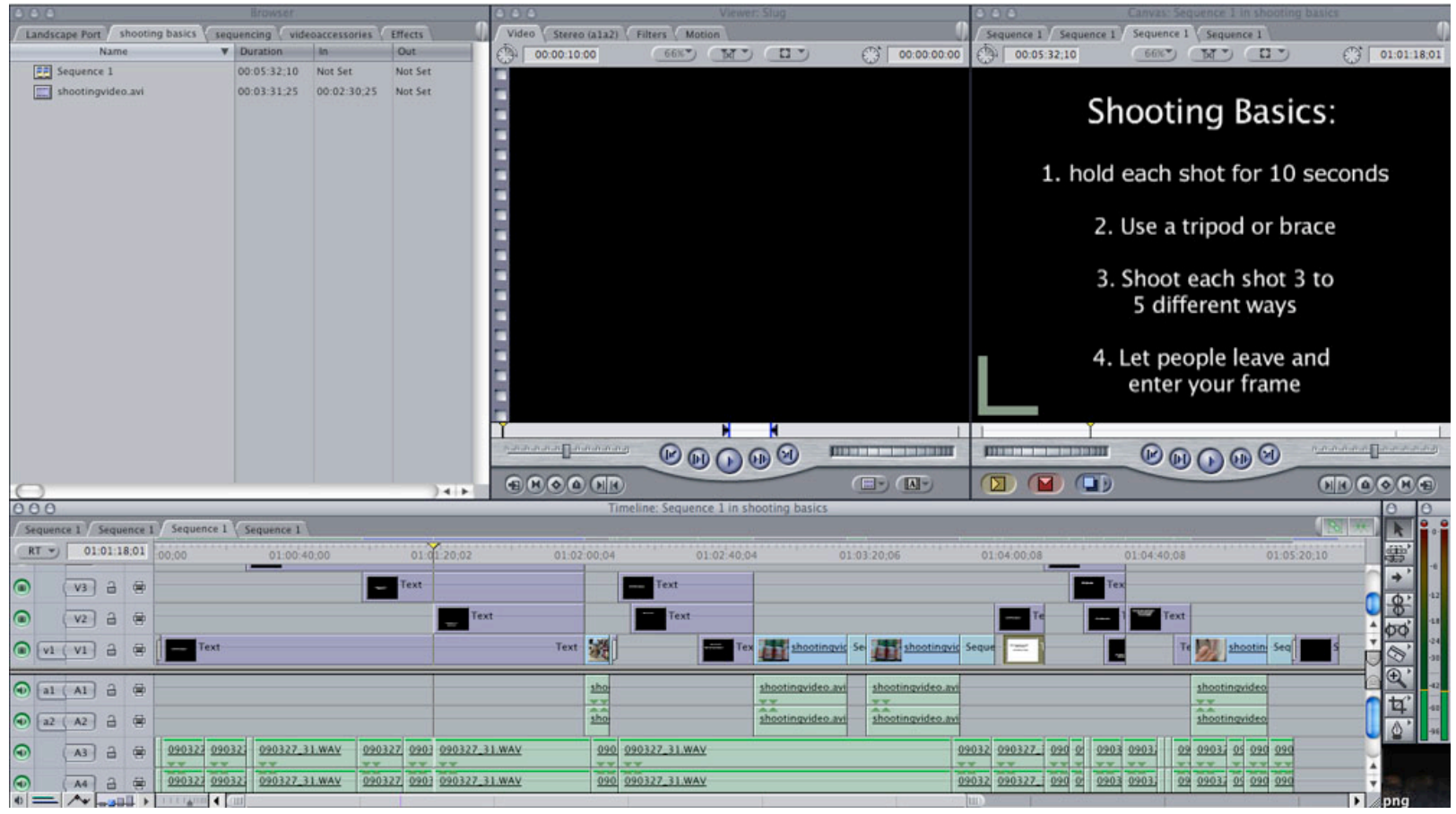

"Video Accessories"

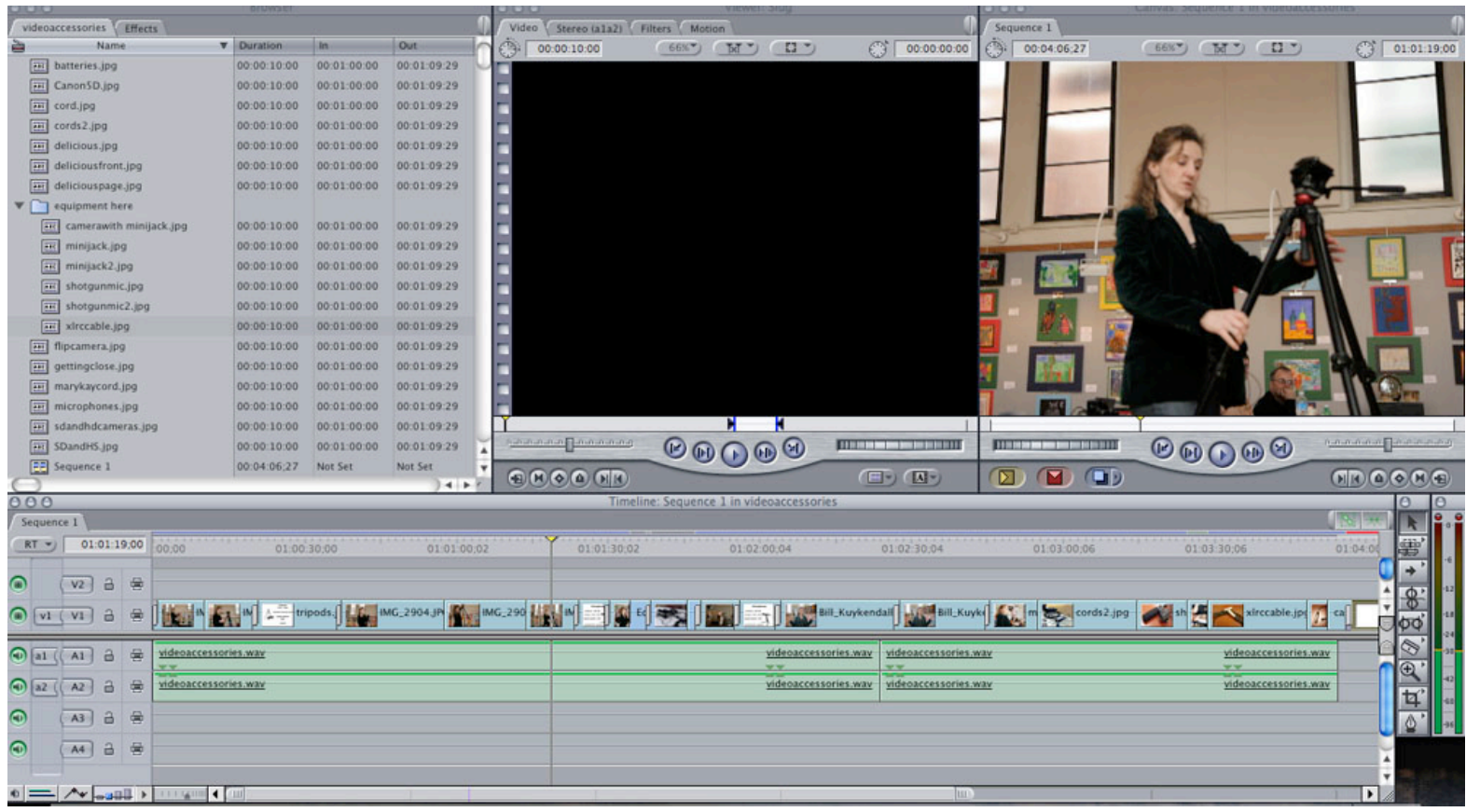




\section{Appendix 6. eTrainer Design Sketch}

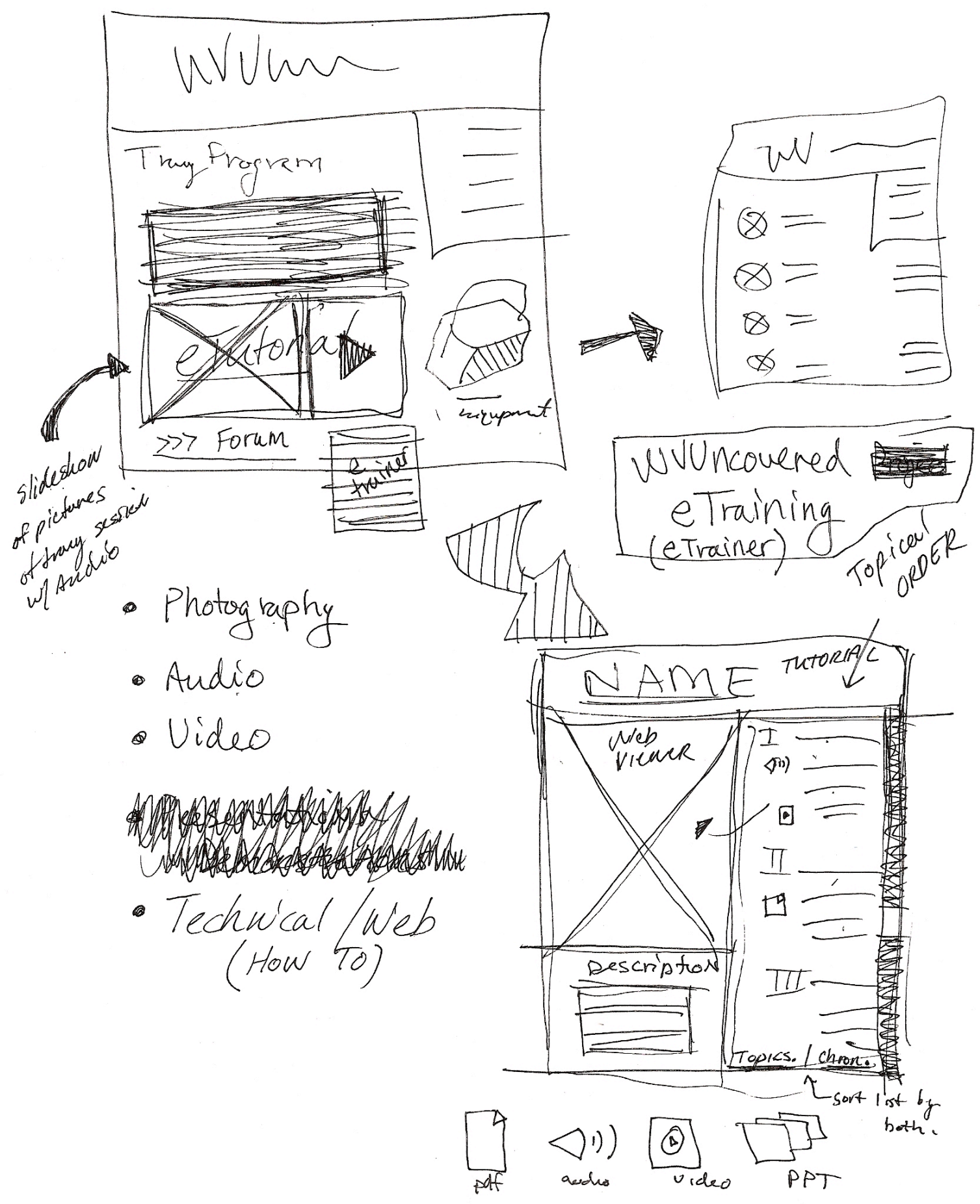

